\title{
Irkçılık ve Nefret Söylemi Bağlamında George Floyd'un Ölümü Haberlerinin Analizi
}

\author{
DOI: 10.26466/opus.774524
}

*

\section{$\frac{\text { Ciğgdem Tosun * }}{{ }^{*} \text { Dr. }}$}

E-Posta: cigdemtosun865@gmail.com

ORCID: $\underline{0000-0001-9305-1453}$

\section{Öz}

ABD'de 25 Mayıs 2020 tarihinde George Floyd'un öldürülmesi sonrasindaki olaylar kitlesel tepkiye dönüşmüş ve diğer ülkelere de yayılmıştır. Bu çalışmada www.amerikaninsesi.com haber sitesinde George Floyd haberleri ırkçılık ve nefret söylemi bağlamında incelenmiştir. Çalışmanın amacı Amerika'da polis şiddeti sonucu hayatın kaybeden George Floyd'un ölüm haberlerinin www.amerikaninsesi.com haber sitesinde nasıl yansıtıldığını ve siyahi olmasının ırkçıllk ve nefret söylemi bağlamında nasıl aktarıldığın tespit etmektir. Amaçsal örneklem yöntemine göre olayın meydana geldiği 25 Mayıs tarihinden sonra ilk haberin yayınlandığı 27 Mayıs ve 2 Haziran tarihleri arasındaki bir haftalık süre çalışma kapsamına alınmışıır. Bir haftalık süreçte imzasız olarak yayınlanan on yedi haber incelenmiştir. Haberde kullanılan dikkat çekici, anlam üreten fotoğraflar da çalışma kapsamına alınmıştır. Yöntem olarak Teun A. van Dijk'ın eleştirel söylem analizi kullanılmıştır. Incelenen haberlerde Floyd'un ölümü sonrasındaki şiddet olaylarına dikkat çekildiği görülmüştür. Ana olay ve haber öznesi önemsizleştirilmiş̧ir. Ana olay protestolar olarak sunulmuştur. İdeoloji ve anlam yüklü fotoğraflar kullamılmıştır. Haberlerde siyahiler suç, yoksulluk, şiddet ve yă̆ma ile ilişkilendirilmiştir. Göstericiler ve polis karşıtlı̆̆ açıklamaları aktif cümlelerle aktarllarak söylemleri yeniden üretilmiştir. Haberlerde ötekileştirici, özneyi önemsizleştirici sözcüklere yer verilmiştir. Haberlerde göstericilerin söylem ve açıklamalarına yer verilmemiştir. Yargılamanın adil olup olmadığı, toplumda siyahilerin karşılaştıkları ırkçı ve ötekileştirici yaklaşım üzerinde çok fazla durulmamıştır.

Anahtar Kelimeler: Irkçılık, nefret söylemi, haber. 


\title{
Analysis of George Floyd's Death News in the Context of Racism and Hate Discourse
}

\begin{abstract}
In the United States, the events that followed the murder of George Floyd on May 25, 2020 turned into a mass reaction and spread to other countries. In this study, the news of George Floyd's death on www.amerikaninsesi.com was analyzed in the context of racism and hate speech. The aim of the study is to determine how the news of the death of George Floyd, who died as a result of police violence, was reflected on www.amerikaninsesi.com and how black people were perceived in the context of racism and hate speech. As the first piece news on this incident was published on 27 May, in line with the framework of the purposeful sampling method, the one week period between 27 May and 2 June was included in the analysis conducted in this study. The seventeen pieces of news published in this oneweek period were analyzed in detail. Remarkable and meaningful photographs used in the news were also included in the study. Critical discourse analysis of Teun A. van Dijk was chosen as the research method. Analysis of the news revealed that attention was drawn to the violence that occured after the death of Floyd. The main incident and news subject were trivialized. Protests were presented as the main event. Ideological and meaningful photos were used. In the news, blacks were associated with crime, poverty, violence and looting. Otherization was defined around demonstrators and police opposition. Statements by public institutions and officials were conveyed in the forms of active sentences and their discourses were reproduced. In the news, the words otherizing and trivializing the person were used. The discourses and statements of the demonstrators were not included in the news. Whether the trial was fair or not, othering or the racist approach that Blacks face in society was not emphasized at all.
\end{abstract}

Keywords: Racism, hate speech, news. 


\section{Giriş}

ABD'de 25 Mayıs 2020 tarihinde George Floyd'un öldürülmesi sonrasındaki olaylar, kitlesel tepkiye dönüşmüş ve diğer ülkelere de yayılmıştır. Polis memurunun şüphe üzerine gözaltına aldığ ${ }_{1}$ Floyd'un boynuna diziyle bastırması sonucu, Floyd nefessiz kalarak hayatını kaybetmiştir. Olayı cep telefonuna kaydederek sosyal medyada paylaşan bir görgü tanığı, Floyd'un ölüm anının görüntülerinin yayılmasını ve tepkilerin örgütlenmesini sağlamıştır. Tepkilerin kitleselleşmesinin nedeni polisin $\mathrm{ABD}$ 'de siyahilere uyguladığı ırkçı, ayrımcı politikalar olarak gösterilmiştir. Floyd'un ölümüne sebep olan polis memurunun üçüncü derece cinayetten suçlanması da protestoların artmasına neden olmuştur. ABD Başkanı Donald Trump'ın eyaletlerdeki yönetimlerin şiddeti önlemekte yetersiz olduğunu ve Ulusal Muhafız Birlikleri'ni görevlendireceğini açılaması protestoların şiddetini arttırmakla kalmamış, göstericilerin ötekileştirilmesi süreci çözümsüzlüğe götürmüştür.

Bir kişinin siyahi olduğu için gördüğü şiddet sonucu yaşam hakkının elinden alınmasında, sadece polis şiddeti sorumlu tutulmamalıdır. Toplumsal sistemde siyahilerin nasıl konumlandırıldığı, yasal haklardan ne kadar faydalandıkları, medyanın söyleminde nasıl yer buldukları ve yansıtıldıkları bir bütün olarak değerlendirilmelidir. Polis şiddeti toplumda siyahilere yaklaşımın bir sonucu olarak olumsuz olaylarda kendini göstermektedir. Şiddeti azaltmak ve ortadan kaldırmak, toplumsal yapıdaki ötekileştirici yaklaşımın ve dilin değiştirilmesiyle mümkün olabilecektir. Bu nedenle medyanın söylemi önem kazanmaktadır.

Bu çalışmada www.amerikaninsesi.com sitesinde George Floyd haberleri ırkçlık ve nefret söylemi bağlamında incelenmiştir. Çalışmanın amacı Amerika'da polis şiddeti sonucu hayatın kaybeden George Floyd'un ölüm haberlerinin www.amerikaninsesi.com haber sitesinde nasıl yansıtıldığını ve siyahi olmasının ırkçılık ve nefret söylemi bağlamında nasıl aktarıldığını tespit etmektir. İlk haberin yayınlandığı 27 Mayıs ile 2 Haziran tarihleri arasindaki bir haftalık süre amaçsal örneklem yöntemine göre seçilmiştir. Haberdeki objektifliği analiz etmek için imzasız olarak yayınlanan 17 haber ve haberde kullanılan dikkat çekici, anlam yüklü fotoğraflar çalışma kapsamına alınmıştır. Yöntem olarak Teun A. van Dijk'ın eleştirel söylem analizi kullanılmıştır. 


\section{Irkçılık ve Nefret Söylemi}

Irkçılık, bireyleri veya grupları ırklarına göre ikincileştiren herhangi bir politika, inanç, tutum, eylem ya da eylemsizlik olarak tanımlanabilmektedir. Irk sistemi, belirli düşmanlıkları ve çatışmaları kurmaktadır. (Wolf ve Le Guin, 2004, s. 2) Irkçllık, bir üstünlük ve aşağıllı hiyerarşisi olarak görülmekte ve bu hiyerarşi farklı şekillerde oluşturulabilmektedir. (Grosfoguel, 2016, s. 10) Irkçlık etnik kökeni de içeren bir grup egemenliği sistemidir. Bu sistem hem yapısal hem de ideolojiktir. Eşitsizliğin siyasi, ekonomik ve sosyo-kültürel yapılarını, dışlama ve ötekileştirme süreçlerini ve pratiklerini ve bu yapıların ve süreçlerin gerektirdiği sosyo-bilişsel temsilleri somutlaştırmaktadır. (van Dijk, 1991, s. 27) Irkçlık sadece bir grup iktidarı biçimi değildir, temel olarak diğer iktidar biçimlerinin de bir işlevidir. Gerçekte, ırkçıllk bu diğer iktidar biçimlerinin desteklenmesinde veya meşrulaştırılmasında etkili olabilmektedir. (van Dijk, 1991, s. 30) Bir grubun öteki üzerindeki egemenliği, sistemin eşitsizliklerinin sürdürülmesini gerektirdiğinden, bu eşitsizliği haklılaştırıcı unsurlar ileri sürülmeye çalışılmaktadır. Irkçılık da grup egemenliğini kurmak adına siyasi, ekonomik, toplumsal alanda kurulan iktidar biçimlerinin temellendirilmesinde kullanılmaktadır.

Irkçılık biz-öteki karşıtllğını yaratmanın en eski gerekçelerinden biri olmuştur. Bir toplum ya da grubun kendi içinde bütünlüğünü sağlaması, ötekinin varlığına ve tanımlanmasına bağlı görülmüştür. Ötekinin kim olacağı konusunda da ırk, etnik köken, cinsiyet, inanç gibi gerekçeler ileri sürülmüştür. Biz-öteki karşıtlığı, tanımlamanın ötesinde, güçlü-zayıf karşıtlığının da kodlanmasını gerektirmiştir. Güç dengesindeki eşitsizliğin sürdürülmesi sağlanarak, 'biz'i yüceltmek hedeflenmiştir.

Modern hukuk, insanların kendilerine benzer olmayan diğerinin moral bakımından değersizleştirilmesine engel olamamıştır. İnsanların sadece soyut olarak haklara sahip olmaları, eşitlenmeleri için yeterli olmamış, aynı zamanda bu hakları gerçekleştirebilecek güce sahip olmaları gerekliliği, ikinci kuşak insan hakları tarafından tanımlanmıştır. İnsan gruplarının güç bakımından eşit olmamaları, 'ben' ile 'diğeri' arasındaki ilişkiyi hiyerarşik hale getirmiş, tahakküm ilişkisine dönüştürmüş ve ayrımcllı̆̆a yol açmıştır. İkinci kuşak insan hakları, insanları güç bakımından denkleştirme anlayışına dayalı olduğundan, herkesin aynı tür özelliklere sahip olduğu tezine dayanmıştır. Ancak dünyada özellikleri bakımından birbirinden farklı olan, 
toplumsal konumları bakımından eşit olmayan insanlar bulunmaktadır. (Göregenli, 2013c, s. 25) Kendine benzer olmayanın değersizleştirilmesi, 'diğeri' olarak tanımlananlara haklarını gerçekleştirecek gücün yasal anlamda sağlanmamasından ve bu hakkın korunmamasından kaynaklanmaktadır. Haklarını koruma ve kullanma yetkisinin pratikte karşılık bulmaması, yasanın dışında topluma da bağlı olmaktadır. Toplumsal sistem içinde azınlık olanların ya da ötekileştirilenlerin haklarının pratikte korunmaması, sistemin işleyişi açısından karşı çıkılması gereken bir sorun olarak algılanmadıkça, çözüm getirilmesi güçleşmektedir. Her ötekileştirilme pratiği yasa da karşılık bulamayabilmektedir. Karşılık bulmayan bu tür durumlarda da toplumsal kanaatin somutlaştı̆̆ davranış önem kazanmaktadır.

Yasalar ve ayrımcılığı yasaklayan normlara rağmen, azınlıklar genellikle göç ve yerleşim hakları, yeterli istihdam, barınma, eğitim, sağlık, güvenlik, refah, yasal savunma, saygı, statü ve diğer koşullar gibi tam bir eşitlik tanımlayan maddi veya sembolik kaynaklara daha az erişime sahiptir. (van Dijk, 1991, s. 28) Bu maddi ve sembolik kaynaklara erişim konusunda düzenlemelerin olmaması, hak kavramının soyut kalmasına neden olmaktadır. Eşitsiz yapıların sürdürülmesi, farklılıkların artmasına ve azınlıkların erişim olanaklarının daha da azalmasına yol açmaktadır. Azınlık kavramı da her zaman niceliksel bir tanımlama olmamakta, bazen de niceliksel olarak çoğunluk olanlar temsil olanağı bulamadıklarından azınlık olarak adlandırılmaktadırlar. Herkese eşit temsil hakkının sağlanması konusunda, gücü elinde bulunduranların bu eşitsiz yapının karşısında olmaları çözüme katkı sunmaktadir.

Kendini olumlu sunmanın genel stratejisi, diğerini olumsuz sunmanın genel stratejisini söylemsel olarak mümkün kılmakta ve meşrulaştırmaktadır. Bu nedenle özellikle elitler arasında, toplumdaki ahlaki liderler olarak bir benlik imajını da ifade etmektedir. Buna ek olarak, ötekileştirilen diğer beyaz seçkinlerin de, azınlık gruplarıyla birlikte ayrımclık, önyargı ve ırkçılığa karşı direniş̧e önemli bir rol oynadıkları vurgulanmalıdır. (van Dijk, 1993, s. 283) Kendini olumlu sunmak, diğerini örtülü bir şekilde olumsuz sunmaya neden olurken, ötekileştirilme pratiğinin karşısında durmak ve biz-öteki tanımlamalarını geçersiz kılmak için 'beyaz seçkin' nitelendirmelerini belirli bakış açılarıyla ilişkilendirmeden direniş göstermek gerekmektedir. Irkçılık, ayrımcılık ve önyargılara karşı olmak sadece azınlık olanlara atfedilecek bir davranış biçimi olarak da sunulmamalıdır. Haksızlığa karşı 
durmak da bir duruşu ve kimi zaman da bir bedel ödemeyi gerektirmektedir.

Uyum sağlamak kolay, ayrıcalığa ve prestije çıkan en kestirme yol olarak görülmektedir. Karşı çıkmak ise ölüm mangaları, psikiyatri hapishaneleri ya da toplama kampları gibi denetim araçları bulunmayan bir toplumda bile ağır olabilecek bedeller ödemeyi gerektirebilmektedir. (Chomsky, 2012, s. 15) Bu bedeller en basit düzeyde azınlıkların karşılaştı̆̆ ötekileştirme pratiklerine maruz kalmakla başlamaktadır. Bu zorlu süreç ırkçılık ve ayrımcılığa karşı durmanın önünde bir engel teşkil etmektedir. Susturulan azınlığa, gönüllü olarak susanların eklenmesiyle sorun kamusal alanda görünmez olmakta ama yine başka bir olayda gün yüzüne çıkmak için tetikte beklemektedir.

"Şiddete dayalı kadın düşmanlığıyla, yabancı kültür korkusuyla, yabancı ideoloji ve 'içerideki düşman' korkusuyla rrkçllıkta kendini gösteren şey şudur: Bilinen sinırlar olmadığı takdirde her şey, mikrop dolu kargaşalı bir ortam içinde yok olup gidecek, kimlikleri eriyip yok olacak ve 'Ben', boğulacak ya da ezilip mahvolacaktır." (Donald, 1988, s. 44'den Akt.: Morley ve Robins, 2011, s. 75)

'Biz'i tanımlayan her özellik olumlu sunulduğundan ve 'biz'i tanımlamakta 'öteki' referans alındığından, sınırların aşılması 'biz' in varlığını tehlikeye atacak bir durum olarak yansitılmaktadır. 'Biz'i, 'öteki' üzerinden tanımlamak, aslında 'biz' kavramının içinin doldurulamamasından kaynaklanmaktadır. Irkçılık da 'biz' kavramına gerekçe sunarak, korunmak istenen kimliği oluşturan bir unsur olarak var edilmeye ve korunmaya çalışılmaktadır. Bu da rrkçılık gibi ötekileştirme pratiklerinin söylemde sürdürülmesine neden olmaktadır.

Nefret söylemi ırkçılıktan beslenmektedir. Farklı etnik grupları toplumda korku ve kaygı kaynağı olarak göstermekte ve düşman olarak tanımlamaktadır. (Çomu ve Binark, 2013, s. 209) Demokrasiyi yerleştirme ya da koruma isteği duyulduğunda demokrasi düşmanları gibi bir ifadeye ihtiyaç duyulmaktadır. (Chomsky, 2012, s. 167) Nefret söylemi, öteki olanı tanımlamak için kullanılan olumsuz niteliklerin bir bütünü olmaktadır. Ayrımcı, önyargılı bir dilin hakim olduğu nefret söylemi, ötekileştirilen kitleyi toplumdaki sorunların kaynağı olarak göstermekte, düzen bozucu unsurlar olarak sistemin dışında konumlandırmaktadır. Nefret söylemi, yasalardaki eşitliğin toplumsal yapıda karşılık bulmamasının bir göstergesi olmaktadır. 
Nefret söylemi her zaman Barthes'in ifade ettiği düz anlam düzeyinde de karşımıza çıkmamaktadır, yan anlamlar üzerinden işleyen ve fark edilmeyen ötekileştirici söylem, eşitsiz yapının dil üzerinden sürdürülmesine neden olmaktadır.

Nefret söyleminin tümü aynı değildir ve sonuçları bir ortamdan diğerine farklılık gösterebilmektedir. Üstelik, nefret söylemi hemen fark edilmeyen zararlar ürettiğinde, bu zararlar belirsiz ve ölçülmesi zor olabilmektedir. Ayrıca, nefret söyleminin etkisi, iletişim ortamına önemli ölçüde bağlı görünmektedir. (Rosenfeld, 2001, s. 50) Nefret söylemi kurmak ya da kullanmak, yabancı düşmanlığı yapmak, kültürel üstünlük ya da aşağılamalarda bulunmak da dolaylı ve kültürel şiddet olmaktadır. (Arsan, 2005, s. 128) Dolaylı ve kültürel şiddetin söylem düzeyinde belirsiz bir şekilde işlemesi ölçülmesini zorlaştırırken, nefret söyleminin zihinleri yönlendirmesi daha kolay olmaktadır. Açk bir şekilde ifade edilmeyen nefret söylemi herhangi bir dirençle de karşılaşmamaktadır.

Başkan Donald Trump'ın popülerleştirdiği 'siyasi yanlışlık", gizli ya da açık ırkçı fikirlerin, siyasal söylemin ve sosyal medyanın kamusal alanında, normalleştirilmesine izin veren bir gösterge haline gelmiştir. Trump'ın 'politik olarak yanlış' ideoloji ve dil tarzının sürekli normalleştirilmesi, ırksal şiddetin artmasına ve rrksal olarak farklı etkilerle neoliberal politikanın oluşturulmasına yol açabilmektedir. (Gantt Shafer, 2017, s. 1) Söylemi siyasi yanlışlık olarak tanımlamak, nefret söyleminin etkisini ortadan kaldırmamaktadır. Söylemin taraftarlarınca tekrar edilerek yeniden üretilen nefret söylemi pekişmektedir. Söylemin medyada haber metinlerinde yeniden inşa edilerek üretilmesi de nefret söyleminin yaygınlaşmasına neden olmaktadır.

\section{Haber Söyleminin Ötekileştirme Pratiklerine Etkisi}

Teun A. van Dijk, toplumsal boyutta ideolojilerin medya aracılığıyla kamusal söylemi biçimlendirmesinin, bireysel boyutta sosyal bilişin biçimlendirilmesiyle mümkün olduğunu belirtmektedir. Medya söylemiyle topluma aktarılan ideolojiler bireylerin belirli bir gruba yönelik tutum ve inançlarını oluşturan sosyal temsilleri etkilemektedir. Sosyal temsiller, bireylerin kamusal alandaki etkileşimleriyle yeniden anlamlandırılmakta ve hakim ideolojilerin yeniden tanımlanmasını sağlamaktadır. Medya söylemler aracılığıyla ideolojileri aktarmakta ve yeniden inşa etmektedir. Hakim ideolojilerin taş1- 
yıcısı olan sembolik elitler ve kurumlar, bu aktarım sırasında medyaya eşlik etmektedir. (Göregenli, 2013b, s. 59) Medya egemen söylemin yeniden üretiminin aracı olarak, sembolik seçkinlerin söylemlerini aktarmakta ve kamuoyunun oluşmasına katkı sağlamaktadır. Kamusal alandaki etkileşim de egemen söylemi pekiştirmekte ve güçlendirmektedir.

Medyanın yapısı yerleşik yapıya uyum sağlamayı özendirecek biçimde düzenlenmektedir. (Chomsky, 2012, s. 15) Medyanın işlevi insanlara ne düşünmelerini değil, dikkatlerini neye yöneltmelerini ifade etmeye dayanmaktadır. (Bourse ve Yücel, 2017, s. 212) Medyanın kamusal alanda egemen söylemi hakim kılması için uyum sağlamayı özendirmesi, karşı çıkmayı da ötekileştirmesi gerekmektedir. Bu amaçla medya kamusal alanda gündeme getirilecek ve getirilmeyecek konuları belirlemektedir. Gündemde tutulması gerekenler egemen söylemi yeniden üretirken, egemen söyleme karşı olanların gündeme getirilmemesi gerekmektedir. Karşı söylemlerin ve medyanın gündeme getirmek istemediği konuların yok sayılması ya da manipüle edilmesi ile kamusal alan şekillendirilmektedir.

Medyanın gizlediği konular hakkında genel bir tartışma olmaktadır ve bu tartışma eleştirel olup bazı noktalarda da zekice sürdürülmektedir, ancak nedensiz bir şekilde dağınık kalmaktadır. (Debord, 2017, s. 220) Tepki görmeyen yalan, ilk olarak sesini duyurma yeteneğini kaybeden ve sonrasında tamamen ortadan kalkan kamuoyunu yok etmeyi başarmaktadır. (Debord, 2017, s. 172) Tartışmaların nedensiz bir şekilde dağınık kalması, sembolik seçkinlerin ve kurumların medyada daha fazla yer bulmasından, medyanın bu söylemleri egemen bakış açısıyla yeniden sunmasından ve karşı söylemleri görmezden gelmesinden kaynaklanmaktadır. Medyanın kamuoyu oluşumuna katkısı, sakınca görülmeyen konulardaki tartısmaların bir düzen içerisinde tekrarlanarak sürmesine olanak tanırken, karşı söylemlerin alternatif medya kanallarını ve yeni medyayı kullanarak bir tepkiyi örgütleyebilmesi her zaman ve durumda başarılı olamamaktadır.

Medya adeta bir yanılsama bombardımanına tutarak bilinçleri sindirmekte, hayal dünyalarını yağmalamaktadır. Güncellik adına her zaman yeni ama sansasyonel ve anlamsız olaylar üretmektedir. Alt düzeye indirgenmiş düşünce yapısını egemen hale getirmektedir. Artık izleyicilerin ruhlarını meşgul eden kapsam kendi ürünleri değil, medya ürünü olmaktadır. (Göka, 2011, s. 22) Medya ilginç olayları haberleştirerek dikkatleri asıl konudan uzaklaştırmakta ve sansasyonel, magazinsel içeriklerle zihinleri oya- 
lamaktadır. Sorgulamayan bir kitle yaratmaya çalışarak karşı söylemlerin ortaya çıkmasını da engellemektedir.

Haberleri hazırlayıp sunanlar, yorumlayanlar, her şeyden önce birer satış elemanıdırlar. Haberlerin yanına ilgiyi çekebilmek için ne tür ilaveler yapabileceklerini bulmak için kafa yormaktadırlar. Kent hayatında görülen çürüme, cinayetler, ırkçı eylemler, çevre kirlenmesi ve savaş milyonlarca insanın günlük hayatının birer parçası olmaktadır. (Schiller, 2005, s. 239) Çatışma haber değeri taşıdığından bu tür haberlerle gündem kısa süreli olarak değiştirilmektedir. Çatışmalı ve sansasyonel olaylara odaklanan zihinler, arkasındaki asıl konuları sorgulamamaktadır. Irkçı olaylardaki şiddeti seyrederken, arka plandaki eşitsiz egemen söylemi görmezden gelmektedir. Şiddetin asıl olarak söylemdeki eşitsizlikle başladığını fark edememektedir.

Toplumsal görünürlükleri çeşitli baskılar, tarih ve deneyim yüzünden azalmış olan azınlık gruplarına dair kanılar, çoğu zaman medyada bu gruplarla ilgili haberlerin taşıdığı imalar, ifadeler, tanımlamalar ve sınırlandırmalarla yaratılmaktadır. Bu kalıp yargıların ve önyargıların ortaya çıkmasında haber dışındaki medya içeriği etkili olmasına rağmen, haberde yer verilmesi, bu yargıların teyit edilmesi anlamı taşımaktadır. (Çınar, 2013, s. 142) Medyanın hiçbir yorum katmadan söylemi aktarması bile yaygınlaşarak kabul edilebilir hale gelmesine sebep olabilmektedir. Medya iyi ve kötü tanımlamalarını kendisi yaparak yoruma kapatmaktadır. Azınlıklar haberde temsil olanağı bulduklarında olumsuz sıfatlar ve adlandırmalar kullanılarak yansıtılmaktadır. Haber söyleminde azınlıklar ya olumsuz olayın öznesi ya da kurbanı olarak gösterilmektedir. Kurban olarak yansitıldıklarında da, haberde olay ön plana çıarılarak özne önemsizleştirilmektedir.

Kurbanı değersizleştirmek ya da kurbanın acı çektiğini yadsımak eğilimi, adil dünya inancını sürdürmek ve korumak için izlenen stratejiler olmaktadır. (Göregenli, 2013a, s. 44) Haberde kurban olarak gösterilen özneyi ön plana çıkarmak, eşitsiz yapının ortaya çıkmasına neden olmakta ve böylece adalet, hukuk, demokrasi söylemlerini sürekli tekrar eden seçkinlerin iktidarını sarsmaktadır. Yayılma hızı söylem ya da olayın daha kabul edilebilir olmasına neden olabilmektedir.

Yeni medya ortamı, nefret söyleminin hızlı bir şekilde paylaşılmasını sağladığından doğallaştırılmasına yol açmaktadır. Sanallık özelliği kullanıcının ortama gönüllü ve her türlü statünün kısıtlamasından uzak bir şekilde katılım olanağını da vermektedir. (Binark, 2010, s. 27) Gönüllü ve statü kısıt- 
lamalarından arınmış bir katılımın, ticari ve egemen medyanın hegemonyasına bir karşı duruşu sergilemesi sürece katkı sağlamaktadır.

Enformasyon üretiminin egemen biçimlerine ve ticari medyanın hegemonyasına bir meydan okumayı içeren, katılımcllık yanında yaygınlığı da hedefleyen bir iletişim ortamı tasarlamak önemli olmaktadır. Sosyal medyanın siyasal katılımla ilgili enformasyona hızlı ve aracısız erişim sağladı̆̆ ifade edilebilmektedir. (Aydoğan ve Başaran, 2012, s. 240) Enformasyona hızlı ve aracısız erişimin katılım ile etkileşim boyutuna geçmesi, zihinlerin yönetilmesini engellemektedir. Schiller (2005, s. 283-284) katılım konusunda aktif olma gerekliliğini şöyle açıklamaktadır:

"Eğer bir toplumun bireyleri küçük bir azınlık tarafından beyinlerinin yönetilmesini istemiyorsa, enformasyon olgusunda olabildiğince aktif olmayı kendine namus borcu bilmek mecburiyetindedir."

Enformasyon olgusunda aktif olmak bireylerin göreviyken, medyanın görevi de çatışmalara, şiddete, ayrımcılığa, önyargılara haber söyleminde yer vermemek olmaktadir.

Haber yaparken hak ihlali yapmamak, haberin tanımından kaynakların seçimine, fotoğraf kullanımına, yazımına kadar, gazeteciliğin hak ihlali yapılmasına izin veren standartlarına büyük bir dikkatle yaklaşılması, bunların yeniden tarif edilmesi anlamına gelmektedir. (Alankuş, 2013, s. 245) Haber öznesi olan her bireyin ya da azınlığın haberde sunulmasında, kullanılan dilin, haber başlığının, haber fotoğrafının, olayın bağlamının ve arka planının etkisi olmaktadır. Bu nedenle haber söyleminde bu unsurlara dikkat edilmesi gerekmektedir. Ötekileştirici söylemler toplumda şiddetin artmasına neden olarak eşitsiz yapının sürmesine yol açmaktadır.

\section{Yöntem}

Bu çalışmada www.amerikaninsesi.com haber sitesinde George Floyd haberleri irkçlık ve nefret söylemi bağlamında incelenmiştir. www.amerikanınsesi.com, Voice of America (VOA) medya kuruluşunun haberlerini Türkçe yayınlayan haber sitesidir. 1942 yılında kurulan VOA, her hafta 45'i aşkın dilde yayınlar yapmaktadır. Türkçe yayınlar 12 Şubat 1942'de başlamış, 1945'te bir süre kesilmiş, 1949'da yeniden başlamıştır. ABD Küresel Medya Ajansı'na bağlı olan VOA, tamamen Amerikalılar'ın vergileriyle finanse edilmektedir. (VOA, t.y.) 
Çalışmanın amacı Amerika'da polis şiddeti sonucu hayatını kaybeden George Floyd'un ölüm haberlerinin www.amerikaninsesi.com haber sitesinde nasıl yansıtıldığını, ırkçılık ve nefret söylemi bağlamında nasıl aktarıldığını tespit etmektir. Çalışmanın önemi Amerika'da meydana gelen bu olayla ilgili olarak Amerika kaynaklı bir haber sitesinin verdiği haberlerle diğer ülkelerde nasıl bir imaj çizdiğini, olayları nasıl gösterdiğini, objektif olup olmadığını haber söylemi üzerinden analiz etmektir. Amaçsal örneklem yöntemine göre olayın meydana geldiği 25 Mayıs 2020 tarihinden sonra ilk haberin yayınlandığ 27 Mayıs ve 2 Haziran tarihleri arasındaki bir haftalık süre çalışma kapsamına alınmıştır. Bir haftalık süreçte haberdeki objektifliği analiz etmek için imzasız olarak yayınlanan 17 haber incelenmiştir. Haberde kullanılan dikkat çekici, anlam üreten fotoğraflar da çalışma kapsamına alınmıştır. Yöntem olarak Teun A. van Dijk'ın eleştirel söylem analizi kullanılmıştır.

van Dijk'ın modeli makro ve mikro yapıdan oluşmaktadır. Makro yapı da tematik ve şematik yapıya ayrılmaktadır. Tematik yapıda başlık, haber girişi ve fotoğraf incelenmektedir. Şematik yapıda ana olayın sunumu, sonuçlar, art alan bilgisi, bağlam bilgisi, haber kaynakları ve olayın tarafları üzerinde durulmaktadır. Mikro yapıda ise cümle yapıları, cümleler arasındaki ilişki, sözcük seçimleri ve haber retoriği incelenmektedir. (Özer, 2015, s. 247-248)

Tematik yapı, metnin temalarının ve konularının hiyerarşik organizasyonunu anlamamızı sağlamakta ve bir metnin en önemli bilgisinin ne olduğunu tanımlamaktadır. İlgili konuları ve bu konuların karşılıklı ilişkilerini içermektedir. Tematik analizin temel amacı, her bir haber söylemindeki temaları belirlemek ve bunların metin içindeki koşullu ve hiyerarşik ilişkilerini ve anlamsal özelliklerini kurmaktır. Bu şekilde haberlerdeki farklılıklar görülebilmektedir. (van Dijk, 1988b, s. 72-73) Haberlerin hiyerarşik tematik yapısında dengelilik, tarafsızlık gibi profesyonel normlar silinmektedir. Siyasal ve kültürel yapı içinde egemenliğini kuran söylemler, alıntılar aracılığıyla haberin hiyerarşik tematik yapısında, inanılırlıklarını yeniden kurmaktadırlar. (İnal, 1997, s. 156) Haber metninde temalardan birinin ya da bazılarının ön plana çıkarılması bilinçli bir seçim olmakta ve okuyucu ya da izleyici gündeme getirilmesi ve gündemde tutulması istenilen konular hakkında bilgilendirilebilmektedir. Haber özneleri olumlu ya da olumsuz konular bağlamında yansitılarak kitle manipüle edilmeye çalışılabilmektedir. 
Haberlerde kullanılan başlıklar da, haber metninin tümü okunmadığında, okuyucunun zihninde bir izlenim oluşmasına neden olabilmektedir. Dikkat çekmek için haber metniyle uyumsuz başlıklar ve fotoğraflar kullanılabilmektedir.

Fotoğrafların analizi, durumun ve katılımcllarının temsil edilme biçimlerinden daha fazla çıkarımlar yapmamıza olanak vermektedir. Fotoğraflarda bir olayin ve hala devam eden bir eylemin sadece bir bölümü görülmektedir. (van Dijk, 1988b, s. 282) Haberde kullanılacak fotoğrafın seçimi bile ideolojik olmaktadır. Pek çok haber fotoğrafından sadece bir karenin yayınlanması kimi zaman haberi açıklamakta yetersiz kalsa da, bazen tek bir kare haber metninden daha fazla etki yaratabilmektedir.

Bir haber şemasının varsayımsal yapısında haber raporu özet ve hikayeden oluşmaktadır. Özeti başlık ve haber girişi oluşturmaktadır. Hikayeyi ise durum ve yorumlar oluşturmaktadır. Durum bölüm ve art alan bilgisi olarak ikiye ayrılmaktadır. Bölümü ana olaylar ve sonuçlar oluşturmaktadır. Art alan bilgisini ise bağlam ve tarih oluşturmaktadır. Bağlam koşullar ve önceki olaylar olarak ikiye ayrılmaktadır. Yorumlar da sözel tepkiler ve son kanaatler olarak ikiye ayrılmaktadır. Son kanaatleri de beklentiler ve değerlendirmeler oluşturmaktadır. Haber şemasının, bu varsayımsal yapısında tüm kategorilerden bahsedilmesinin teorik olduğuna dikkat etmek gerekmektedir. Çoğu haber metni bu kategorilerden sadece bazılarına sahiptir. Asgari düzeyde iyi biçimlendirilmiş bir haber söyleminde yalnızca başlık ve ana olaylar zorunlu olmaktadır. Art alan bilgisi, sözel tepkiler ve yorumlar gibi kategoriler isteğe bağlı olmaktadır. Bazı kategoriler ise birkaç kez tekrarlanabilmektedir. (van Dijk, 1988a, s. 55-56) Art alan bilgisi ve olayın bağlamına ilişkin bilgiler çoğu haber metninde bulunmamaktadır. Bu durum, haber olan olayın bağlamından koparılarak tipleştirilmesi ve benzer olayların daha önceden sunumu sırasında kurulan çerçevelerin yeniden kullanılması ile sonuçlanmaktadır. (İnal, 1995, s. 118-119) Her haber tekliğinde değerlendirilmediğinden, bağlam ve art alan bilgisine yer verilmemektedir. Eylemin ya da söylemin meydana geliş koşulları göz ardı edilmekte, yarg1lar ve yorumlar farklılaşmamaktadır. Bu da doğru bir değerlendirilme yapilmasina imkan vermemektedir.

Makro yapıyı tematik ve şematik yapılar oluştururken, mikro yapıyı cümle yapıları ve ardışık cümleler oluşturmaktadır. Cümle yapılarında biçimbilimi, sözdizimi, anlambilimi ve sözcükler incelenirken, ardışık cümle- 
ler arasında uyum ve tutarlılık analizine bakılmaktadır. (van Dijk, 1988b, s. 17) Haber söyleminde yerel uyum, cümlelerde ifade edilen önermeler arasında genelleme, karşıtlık, açıklama gibi işlevsel ilişkilerin veya neden-sonuç gibi zamansal ve koşullu ilişkilerin olması şeklinde açıklanmaktadır. (van Dijk, 1988b, s. 104) Cümle yapıları da, haberlerde altta yatan ideolojik konumları ortaya çıkarabilmektedir. Seçkin veya güçlü grupların olumsuz eylemlerini örtbas etmek için cümlelerde pasif yapılar kullanılabilmekte ve tipik özne konumlarından haber öznesi silinebilmektedir. (van Dijk, 1988a, s. 177) Olumsuz olaylarda seçkin özneyi daha silik göstermek için edilgen cümle yapıları kullanılırken, olumlu olaylarda seçkin özneyi yüceltmek için etken cümle yapıları kullanılmaktadır. Egemen söylemin dışında kalanlar söz konusu olduğunda ise, olumsuz olaylarda etken cümle yapıları kullanılarak haber öznesi ön plana çıkarılırken, olumlu olaylarda edilgen cümle yapıları kullanılarak haber öznesi önemsizleştirilmektedir.

Haberlerde belirli kelimelerin seçimi tutumlara ve ideolojilere işaret edebilmektedir. Gazetenin aynı kişiyi belirtmek için teröristi mi yoksa özgürlük savaşçısını mı seçeceği, ima edilen dolaylı bir ifade olarak sadece anlambilimsel bir sorun değildir. Haber medyasında ideolojik temelli sözcük çeşitliliğinin bu standart örneğinin yanı sıra, çoğu daha incelikli olmasına rağmen bu tür fikir kontrollü sözcük seçimleri bol bulunmaktadır. (van Dijk, 1988a, s. 81) Sözcük seçimleri, ideoloji ve tutumlara işaret etmekle birlikte, sözcüklerin kullanıldıkları cümle yapıları, bağlam ve retorik de önemli olmaktadır.

Söylemin retoriği şeylerin nasıl söylendiğiyle ilgilenmektedir. Bilişselanlamsal düzeyde, insanların bir olay ya da durum hakkında söylenenleri anlaması beklenmektedir. Ancak dinleyici veya okuyucunun ne demek istediğimizi çok iyi anlaması bile, iletişimin amacının yarısını karşılamaktadır. Dinleyici veya okuyucuların söylenenleri kabul etmesi, iddia edilenlere inanması, istenilen eylemleri gerçekleştirmesi beklenmektedir. (van Dijk, 1988a, s. 82) Söylemin eylem halini alması ideolojiye güç kattığından, kitleleri harekete geçirmede retorik önemli bir işlev yüklenmektedir.

Bu çalışmada da haberlerde başlıklar, haber girişleri ve fotoğraflar incelenerek uyumlu olup olmadıklarına bakılmıştır. Ana olayın nasıl sunulduğu, art alan ve bağlam bilgisinin olup olmadığı, haber kaynaklarının kim olduğu, olayın tarafları arasında nasıl karşıtlık kurulduğu analiz edilmiştir. Cümlelerde etken fiil mi edilgen fiil mi kullanıldığı, hangi anlam yüklü sözcük ve fotoğrafların seçildiği ve haber retoriği incelenmiştir. 


\section{Haberlerin Analizi}

Olay 25 Mayıs 2020 tarihinde meydana gelmiş, ilk haber 27 Mayıs tarihinde yayınlanmıştır. Haberin başlığı “ABD'de Siyah Floyd'un Ölümü Tepkiyle Karşılandı" olarak verilmiştir. Başlıkta 'siyah' sıfatına yer verilmeden de başlık atılabilecekken, Floyd'u kastetmek için kullanılan 'siyah' sıfatıyla ötekileştirme yapılmıştır. Siyahileri kastetmek için 'siyah' sözcüğünün kullanılması da anlamı önemsizleştirmektedir. Ölümün tepkiyle karşılanması ve siyahi olmasının vurgulanmasıyla, siyahi olmak ve tepki göstermek arasında nedensellik ilişkisi kurulmuştur. "Minneapolis'te bir siyahın polis şiddeti sonucu öldürüldüğü yerde protesto eylemi düzenlendi" alt başlığıyla "bir siyahın" ifadesiyle ötekileştirme tekrarlanmıştır. Haberin girişinde Floyd için "dolandırııılık suçuyla yakalanan siyah şüpheli" ifadesi kullanılarak, siyah olması ve suçlu olması arasında nedensellik kurulmuş ve genelleme yapılmıştır. "beyaz bir polis "sahtecilik" şikayeti üzerine eşkal benzerliği nedeniyle George Floyd'u gözaltına almak için yere yatırdı." cümlesinde "beyaz bir polis" ifadesiyle karşıtlık kurulmuştur. Haber kaynağı olarak görgü tanıklarının telefon görüntüleri kullanılmıştır. "kelepçeli olan siyah şüphelinin yerde defalarca "Lütfen, nefes alamiyorum, lütfen" diye yalvardığı, bir süre sonra da hareketsiz kaldığı, ancak polisin dizini çekmediği görülüyor." cümlesi de telefon görüntülerine dayanılarak edilgen fiille yazılmıştır. Şüphelinin kelepçeli olduğu vurgusu, polis şiddetinin orantısız olduğunu aktarmaktadır. Federal Bureau of Investigation (FBI)'in polislerin görevden uzaklaştırıldıklarını belirttiği açıklama ile yetkililerin duruma müdahalesi hakkında da bilgi verilmiştir. "Ancak gözaltına alınma şekli, siyahlara yönelik şiddet tartışmalarının dinmediği ülkede, büyük öfke yarattı." cümlesiyle bağlam bilgisi verilmiştir. Siyahilere yönelik şiddetin daha önce de olduğu ve çözümlenemeyen bir konu olduğu bildirilmiştir. Minneapolis Belediye Başkanı Jacob Frey'in Afrika kökenli Amerikalılar'dan özür dilediği belirtilerek, "Amerika'da siyah olmak, ölüm cezası olmamalı" söylemi verilmiştir. Olaya resmi yetkilinin tepki gösterdiğinin aktarılması, ırkçı bakış açısının onaylanmadığını desteklemek için kullanılmıştır. "Görüntüyü izleyen uzmanlar, polisin ya iyi eğitilmediğini, ya da eğitimini hiçe saydığ1n1, dizini çok uzun tuttuğunu söylüyor." cümlesi ile polisin orantısız şiddeti uzman görüşüne dayandırılarak aktarılmıştır. Haberin devamında Amerika'da siyahilerin karşılaştıkları şiddet olaylarına örnekler verilerek, art alan 
bilgisi verilmiştir. Siyahilerin şiddetin mağduru olduğu örnekler ırkçı sald1rıların sıradanlaştığı izlenimi vermektedir. Fotoğraf 1'de olayı protesto eden siyahi ve sol elini yumruk yaparak havaya kaldırmış bir gencin fotoğrafına yer verilerek, olaya gösterilen tepki aktarılmıştır. Fotoğraf 2 'de ise elinde "NO JUSTICE" yazısı tutan beyaz bir kadının fotoğrafına yer verilerek, olayı sadece siyahilerin protesto etmediğinin altı çizilmiştir. Fotoğraflar başlık ve haber metniyle uyumludur.

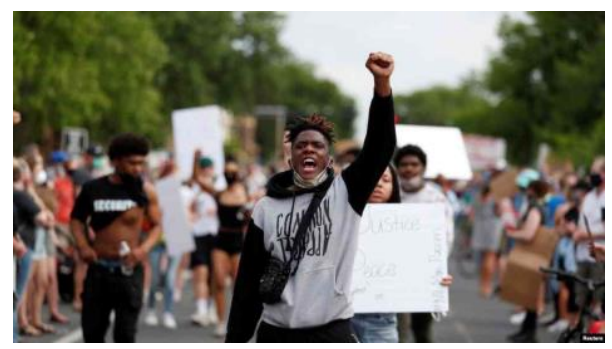

Fotoğraf 1. 27 Mayıs 2020 tarihli haber

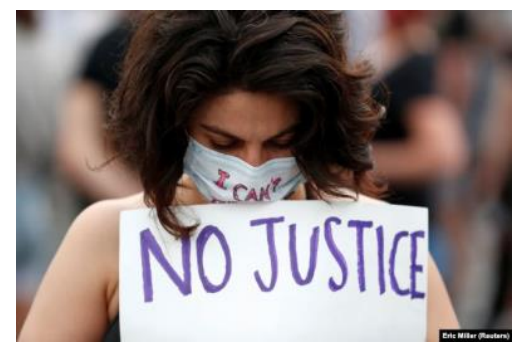

Fotoğraf 2. 27 Mayıs 2020 tarihli haber

28 Mayıs tarihli birinci haberin başlı̆̆ “ "ABD'de Polis Karşıtı Gösteriler İkinci Gün de Devam Etti" olarak verilmiştir. Başlıkta tepkinin polis karşıtı olduğu aktarılmasına rağmen, tepki polislerin karıştığı son olayın özelinde ırkçı bakış açısına ve ötekileştirilmeye karşı olmasına rağmen, sadece polis karşıtı olduğu söylemiyle eksik bilgi verilmiştir. Haberin girişinde "Amerika'nın Minneapolis şehrinde polis karşıtı gösteriler, ikinci gün ve gecede devam etti. Olaylar, polisin siyah bir şüpheliyi gözaltına alırken boğarak ölümüne neden olması üzerine başlamıştı." cümlesi kullanılarak art alan bilgisi verilmiştir. Ana olay polis şiddeti sonucu bir kişinin ölümüyken, gösteriler ana olay olarak sunulmuştur. "Protestolarm ikinci gecesinde göstericilerin bazı yerlerde yangınlar çıkardığı ve işyerlerini yağmaladığı, canlı yayın yapan televizyon kameralarına yansıdı." ifadesiyle göstericilerin ötekileştirilmesi televizyon kameralarına dayandırılarak yapılmıştır. Cümlede pasif bir anlam aktarımı söz konusudur. "Olaylar sırasında en az bir polis aracının da zarar gördüğü belirtiliyor." cümlesinde de bilginin kaynağı belirtilmeyerek, edilgen bir fiil kullanılmıştır. Minneapolis Belediye Başkanı'nın “George Floyd'u öldüren adam neden hapiste değil? Bunu ben ya da siz yapmış olsaydınız, şu an demir parmaklıkların arkasında olurduk" söylemine yer verilerek, şiddet olayına resmi yetkilinin tepki göstermesi yinelenmiş ve "ben ya da siz yapmış olsaydınız" ifadesiyle ayrıcalık tanınanların 
olduğu resmi yetkilinin açıklamasına dayandırılmıştır. Haberde FBI'ın soruşturma başlattığı, FBI ve Hennepin İlçe Savcılığı tarafından soruşturmanın yürütüleceği belirtilerek, kaynağa dayandırılan söylemler aktif bir anlamla sunulmuştur. Siyahilerin daha önce karşılaştığı şiddet olayları aktarılarak art alan bilgisi verilmiştir. Trump'ın soruşturmanın hızlandırılmasını istediği ve Floyd'un ailesine taziyede bulunduğu tweet haberde aktarılarak siyasi aktörün olaya tavrına değinilmiş ve tepkinin şiddetinin artmaması için, tweet ikna edici bir retorik olarak kullanılmıştır. Haberde göstericilerin ve polislerin karşı kaşıya olduğu fotoğraf kullanılmıştır. Fotoğraf 3, göstericilerin olduğu tarafta çekilmiş ve fotoğrafta göstericiler flu, polis ise net gösterilerek polis ötekileştirilmiş̧ir. Polisin silah, jop ve kasklı olması, göstericilerin ise yalnızca ellerini yumruk yaparak havaya kaldırmaları ile polis ve göstericiler arasında güçlü- zayıf karşıtlığı kurularak, polisin orantısız güç kullanımına eleştirel bir bakış da kurgulanmıştır.

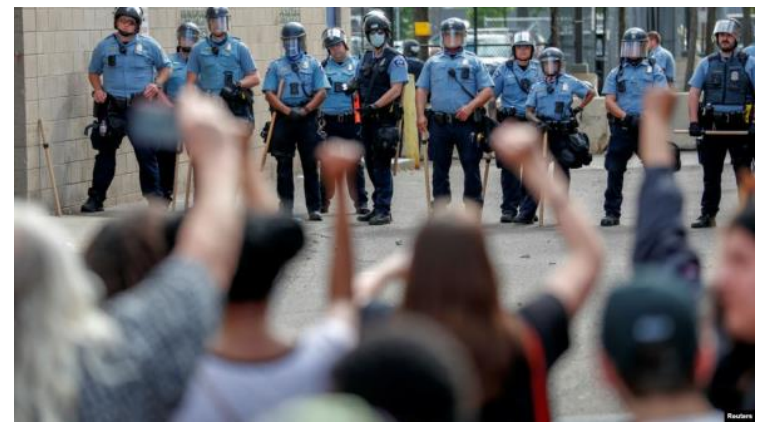

Fotoğraf 3. 28 Mayıs 2020 tarihli 1. haber

28 Mayıs tarihli ikinci haberin başlığı “George Floyd'un Ölümüne Tepkiler Büyüyor Protestolar Yayılıyor" olarak verilmiştir. Başlıkta kişi öğesi ön plana çıkarılarak ana olay üzerinde durulmuştur. Haberin girişinde George Floyd yerine "siyah bir Amerikalı" ifadesi kullanılarak özne önemsizleştirilmiştir. Floyd'un hayatını kaybetmesi sonrasında gösterilerin devam ettiği bilgisi verilerek nedensellik ilişkisi kurulmuştur. "Göstericiler kendilerine plastik mermi ve biber gazıyla müdahale eden polisle çatıştı." cümlesinde göstericiler için etken fiil kullanılmış ve olumsuz anlam taşıyan fiil ile göstericiler çatışmadan sorumluymuş gibi yansıtılmıştır. Haberde "yüzlerini kapatan göstericiler" ifadesi kullanılmış, fakat fotoğraflarda salgın nedeniyle maske takan göstericilerin olduğu fotoğrafa yer verilmiştir. Haberde gös- 
tericilerin mağaza yağmaladığı bilgisinin ardından polisin göstericilere müdahale etmediği belirtilmiştir. Gösterici-polis karşıtlı̆̆ 1 kurularak göstericiler suç işlemesine rağmen polis masum olarak gösterilmiştir. Haberde göstericilerin rafları boşaltmasının mağazanın güvenlik kameralarına yansıdığı belirtilerek, haber görüntü kayıtlarına dayandırılmış ve pasif bir anlatım kullanılmıştır. Gösterilerin diğer eyaletlere sıçradığı bildirilerek bağlam bilgisi verilmiştir. Gösterilerin kitlesel bir tepki halini alması vurgulanmıştır. Trump'ın soruşturmanın huzlandırılmasını istediği ve Floyd'un ailesine taziyede bulunduğu 27 Mayıs tarihli tweet haberde tekrar verilerek, siyasi aktörün gösterilerin şiddetinin azalması yönündeki mesajı ikna edici bir retorik olarak kullanılmıştır. Vali Tim Walz'in sükunet çağrısında bulunduğu tweete haberde yer verilerek resmi yetkilinin açıklamalarıyla da kitleyi yönlendirici retorik kullanılmıştır. Minneapolis Belediye Başkanı'nın ilçe savcısından tutuklamayı yapan memur hakkında suçlama yapılmasını istediği bilgisi verilerek de, resmi yetkilinin söylemi haber kaynağı olarak kullanılmış ve gerekli hukuki süreçlerin işletildiği mesajı verilmek istenmiştir. Yetkililerin olaya karışan dört polis memurunun isimlerini açıkladığı bilgisine ve polis sendikasının "Tıbbi inceleme raporunu beklemeliyiz" açıklamasına yer verilerek, soruşturmanın şeffaf bir şekilde ilerlediği algısı yaratılmaya çalışılmıştır. 2014 yılında siyahi Amerikalı Eric Garner'ın gözaltına alındığı sırada hayatını kaybetmesi haberde verilerek, art alan bilgisi aktarılmıştır. Olaya tepki gösteren sporculara değinilerek, ırkçılık ve polis şiddetinin sadece göstericiler tarafından protesto edilmediği mesajı verilmiştir. Haberin son cümlelerinde olayın gelişimi aktarılarak art alan ve bağlam bilgisi verilmiştir. Fotoğraf 4 ve $5^{\prime}$ te polis müdahalesinden etkilenen göstericilere, Fotoğraf 6 'da ise kasklı, maskeli ve silahlı polislere yer verilmiştir. Gösterici-polis karşıtlığı fotoğraflarda da yansıtılmıştır. Başlık ve metinle uyumlu fotoğraflar kullanılmıştır.

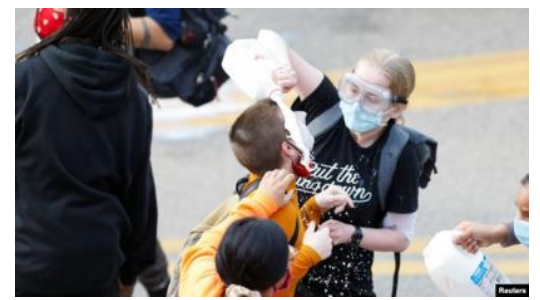

Fotoğraf 4. 28 Mayıs 2020 tarihli 2. haber

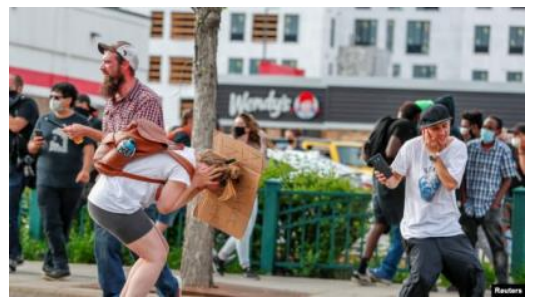

Fotoğraf 5. 28 Mayıs 2020 tarihli 2. haber 


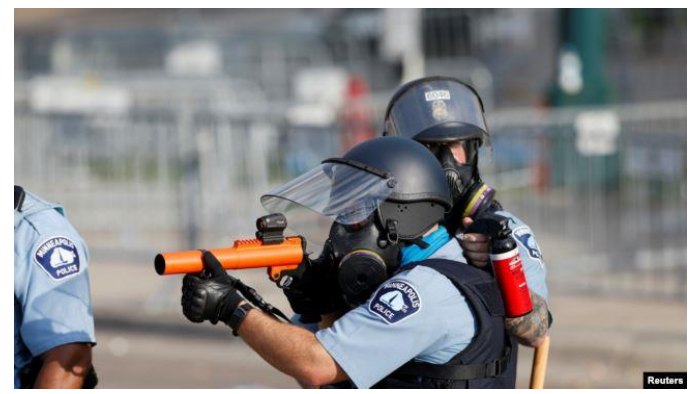

Fotoğraf 6. 28 Mayıs 2020 tarihli 2. haber

28 Mayıs tarihli üçüncü haberde "ABD Adalet Bakanlığı: "Floyd Soruşturması Öncelikli"'” başlığı kullanılmıştır. Başlıkta resmi kurumun açıklaması alıntıyla verilerek soruşturmanın gidişatı konusunda gerekli çalışmaların yapıldığı algısı yaratılmaya çalışılmıştır. Haberin girişinde soruşturma için "bir numaralı öncelik" ifadesi kullanılarak da, resmi makamların olayın çözümüne dair uzlaşmacı tavrına vurgulama yapılmıştır. Olayın meydana gelişi aktarılarak art alan bilgisi verilmiştir. Floyd için "siyah Amerikalı" nitelendirmesi kullanılarak, gösterilen tepkiler ve siyahi olması arasında kurulan nedensellik ilişkisi yinelenmiştir. Deneyimli savcıların görevlendirildiği ve soruşturmanın kapsamlı olduğu bilgisi Bakanlık açıklamasına dayandırılarak resmi makamların uzlaşmacı tavrı pekiştirilmiştir. Resmi makamların açıklamaları haberde öne çıkarılmıştır. Floyd'un kardeşi Philonise Floyd'un göstericilere şiddete başvurmamaları çağrısına, tepkinin şiddetini azaltmak için ikna edici bir retorik olarak haberde yer verilmiştir. Beyaz Saray Sözcüsü McEnany'nin şiddet ve yağmayı durdurma çağrısı, Floyd'un kardeşinin söyleminin ardından verilmiş ve cümleler arasında referansal ilişki kurularak çağrı desteklenmiştir. Bu aynı zamanda hedef kitleyi yönlendirici retorik olarak da işlemektedir. Olaya karışan dört polisten Floyd'un ölümüne sebep olduğu iddia edilen polisin daha önce de polis teşkilatının video kayıt politikasını ihlal ettiği bilgisi verilerek, suç işleyebileceği iddiası desteklenmiştir. Floyd için "Corona virüsü salgını sırasında işini kaybeden milyonlarca Amerikalı'dan biriydi.", "lakabı "Kibar Dev" idi." ifadeleriyle öznelleştirme yapılarak, masum olduğu algısı yansıtılmaya ve polis şiddetinin orantısız olduğu kanaati oluşturulmaya çalışılmıştır. Floyd'un boğazına diziyle bastıran polis, haberde "beyaz bir polis memuru" olarak aktarılarak ırk üzerinden kurulan karşıtlık sürdürülmüştür. Önceki 
haberlerde polis ve göstericilerin olduğu fotoğraflar verilirken, haberde Floyd'u anan insanların olduğu, ana olayla ilgili Fotoğraf 7'ye yer verilmiştir.

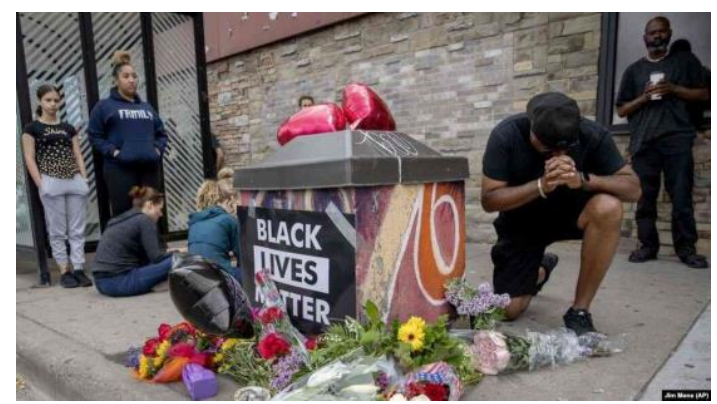

Fotoğraf 7. 28 Mayıs 2020 tarihli 3. haber

29 Mayıs tarihli haber "Floyd'un Ölümünde Polis Memuru Üçüncü Derece Cinayetle Suçlanıyor" başlığıyla verilmiştir. Haberin girişinde "siyah ABD vatandaşı" nitelemesiyle siyahi olmak polis şiddetine maruz kalmakla ilişkilendirilmiştir. Polis için "beyaz polis memuru" ifadesiyle siyah-beyaz karşıtlığ1 yinelenmiştir. Siyah yan anlam düzeyinde ötekileştirileni, mağdur olanı ifade ederken, beyaz egemen olanı, güç kullananı belirtmektedir. Haber cinayet suçunu savcının açıkladığını bildirerek, haber kaynağını yetkililer olarak aktarmış ve habere kesinlik kazandırmıştır. Haberde polis memurunun suçlanmasının protestoların şiddetlendiği olayların ardından geldiğine işaret edilerek, gösterilerin soruşturmanın hızlandırılmasında ve resmi makamların harekete geçirilmesinde etkisi olduğu ima edilmiştir. Olumsuz olarak kodlanan gösterilerin adaletin sağlanmasındaki etkisi olumlu bir değerlendirmeyi ifade etmiştir. Olayların şiddetini azaltmak için Adalet Bakanı'nın olay görüntülerini "son derece rahatsız edici ve yürek parçalay1cı" olarak nitelendirdiği sözlerine haberde yer verilerek, resmi makamların siyahilere ayrımcı bir politika uygulamadıkları belirtilmek istenmiştir. Minneapolis Belediye Başkanı'nı, "Yağma başladığında ateş açma da başlar" tweetiyle eleştiren Trump'ın "Bunların yaşanmasını istemiyorum" açıklamasına yer verilerek, Trump'ın yağma karşısındaki otoriter tavrı yansıtılırken, çatışmanın yaşanmaması konusundaki açıklamasıyla devlet şefkati gösterilmiştir. Valinin görevlendirdiği Ulusal Muhafız Birlikleri için "dünü gözlerden uzak geçirdi" söylemi, zırhlı polis için de "dün geceyse eylemlerin merkez üssü haline gelen Üçüncü Bölge karakolu civarından uzak dur- 
du" ifadesi kullanılarak, göstericilere müdahale edilmediği ve göstericiler ile Ulusal Muhafız Birlikleri ve zırhlı polis arasında bir karşıtlık olmadığı yansıtılmaya çalışılmıştır. Trump'ın "Zorluk çıkarsa kontrolü ele alacağız, ama yağma başlarsa silahlar da konuşmaya başlar" tweeti, "Trump'tan şiddet imalı tweet" ara başlığıyla verilmiştir. Trump'ın tweetinde şiddet açıkça ifade edilmesine rağmen, ima sözcüğü kullanılarak söylem hafifletilmeye çalışılmıştır. Haberin devamında "Ulusal Muhafız Birlikleri ve itfaiyecileri olaya müdahale etmedi." cümlesiyle şiddetin tek taraflı olarak göstericiler tarafından uygulandığı da yinelenmiştir. Haberde olayın başlangıcı ve gelişimi bildirilerek yine art alan bilgisi verilmiştir. "dört polis memuru görevden alınmasına rağmen kentte sosyal çalkantı dinmedi." cümlesiyle polis memurlarının görevden alınması olayın çözümü gibi sunularak, gösterilerin devam etmesi sebepsiz bir durum olarak yansıtılmıştır. Gösterilerin tek bir olayın özelinde siyahilerin karşılaştığı ötekileştirilmeye karşı olduğu verilmeyerek eksik bilgi aktarımı yapılmıştır. Protesto gösterileri için "şiddet eylemleri" ifadesi kullanılarak gösterilerin barışçıl olmaktan uzaklaştığı ve ikna yoluyla engellenemediği ifade edilmek istenmiştir. Haberin devamında "göz yaşartıcı gaz ve plastik mermi nedeniyle kısa süreliğine geri çekilen protestocular daha sonra yeniden bir araya gelerek karakola saldırdı ve polis geri çekilirken binayı ateşe verdi." cümlesiyle göstericilerin karakol binasını ateşe vermesi aktarılarak, polis müdahalesinin de göstericileri durdurmakta yetersiz kaldığı belirtilmeye çalışılmıştır. Minneapolis Belediye Başkanı'nın Trump'ın eleştirilerine karşılık “Biz çok güçlüyüz" söylemi ara başlıkla verilerek karşıtlık ön plana çıkarılmıştır. "Aralarında alkollü içki satan bir dükkan ve indirimli satış yapan bir mağazanın da bulunduğu birkaç iş yeri yağmalandı." cümlesinde birkaç iş yerinden alkollü içki satan dükkanın ön plana çıkarılmasıyla, göstericilerle bağımlılık, suç arasında nedensellik bağlantısı kurulmuştur. Haber metni ve haber fotoğrafları uyumlu olmasına rağmen, başlık haber metnini ve fotoğraflarını yansıtmamıştır. Haberde Fotoğraf 8, 9 ve 10 kullanılarak, protesto gösterilerinden kesitlere yer verilmiştir. 


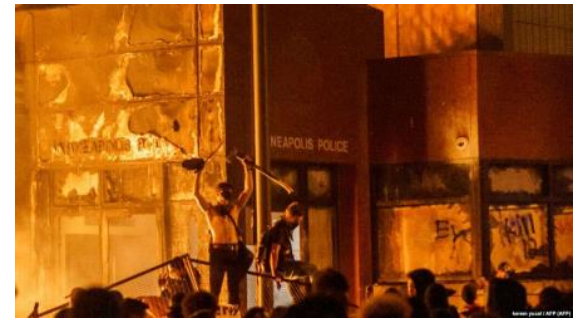

Fotoğraf 8. 29 Mayıs 2020 tarihli haber

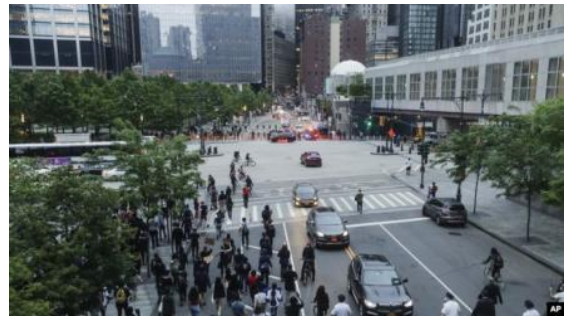

Fotoğraf 9. 29 Mayıs 2020 tarihli haber

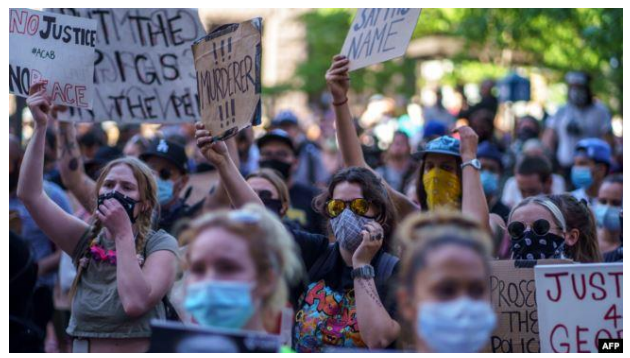

Fotoğraf 10. 29 Mayıs 2020 tarihli haber

30 Mayıs tarihli birinci haber "Trump: "Görüntüler Polis Teşkilatı İçin Hakaret" başlığıyla verilmiştir. Trump, Floyd'un öldürülmesini polis teşkilatı için olumsuz bir durum olarak değerlendirmiştir. Haberin girişinde art alan bilgisi verilmiş ve başlıktaki ifade tekrar edilmiştir. Trump'ın "Barışçıl gösteri hakkını destekliyoruz ama anarşiye izin veremeyiz" söylemi ara başlık olarak verilmiştir. Resmi yetkilinin açılamasına dayandırılan haberde retoriğin kitle üzerindeki etkisi kullanılmıştır. "Floyd'un ailesiyle görüştüğ̈̈nü söyleyen Trump, adaletin yerini bulması konusunda kararlı olduklarını belirtti." cümlesinde Trump'ın uzlaşmacı tavrına değinilirken adalet vurgusu da ön plana çıkarılmıştır. Trump'a yöneltilen "ABD'de polis şiddeti sorunu mu var?" sorusu ara başlık olarak verilmiştir. Sorunun ara başlık olarak verilmesi yetkilinin söylemi olduğu izlenimi yaratmıştır. Soru aynı zamanda şiddet sorununun olmadığı ama var gibi gösterildiği yan anlama gönderme olarak da algılanabilmektedir. Haberin devamında "ABD ve Çin arasında soğuk savaş mı yaşanıyor?" ara başlığı kullanılarak, ABD ve Çin arasındaki virüs salgını gerilimine değinilmiştir. Ara başlık haberin ana başlığıyla, kullanılan fotoğrafla uyumlu değildir. Floyd'un ölümü ana olay olarak sunulup, fotoğrafla desteklenirken, Çin'le ilişkilerin haberde verilmesiyle bağlam dışına çıkılmıştır. Bağlam dışına çıkılması gündemi değiştirme 
amacı da taşımaktadır. Floyd'un anıldığını yansıtan Fotoğraf 11 ile haber içeriği desteklenmiştir.

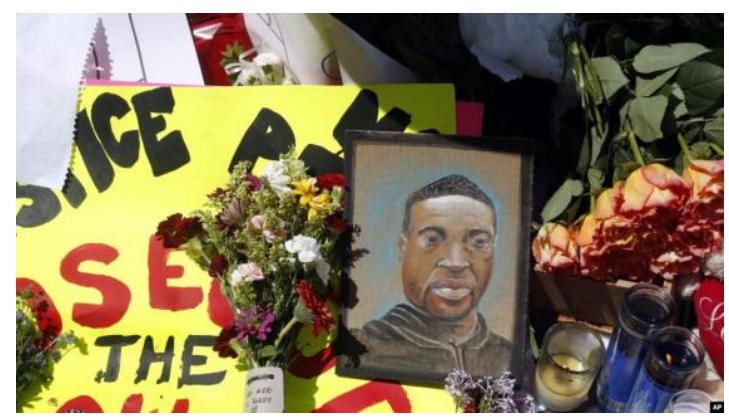

Fotoğraf 11. 30 Mayıs 2020 tarihli 1. haber

30 Mayıs tarihli ikinci haberde "ABD'nin Dört Bir Yanında Protestolara Şiddet Karıştı" başlığı kullanılmıştır. Haberin giriş cümlesinde de Floyd'un ölümü sonrası gösteriler düzenlenmesi aktarılmıştır. Haberde sokağa çıkma yasağı, yağma, şiddet olayları ve polisin biber gazı kullanması verilerek ana olay bağlamında gerçekleşen olaylar zinciri aktarılmıştır. Haberde göstericiler için "CNN World'ün merkezine saldıran", "CNN logosuna sprey boya ile zarar veren", "Dev logoya tırmanan" ifadeleri kullanılarak, göstericilerden ve ana olaydan çok CNN ön plana çıkarılmıştır. Bazı göstericilerin araçlara zarar verdiği, $A B D$ bayrağı yaktığı ve çevredeki binaların duvarlarına Trump karşıtı mesajlar yazdığı etken fiil kullanılarak verilmiş ve olayın öznesi olan göstericiler ön plana çıkarılmıştır. Göstericiler olumsuz olaylar bağlamında yansıtılmıştır. Göstericiler ve Trump arasında karşıtlık kurulmuştur. "Kalabalığı kışkırtmak için tüfekle ateş açmaya çalışan bir kadınsa gözaltına alındı." cümlesinde bilgi resmi makam ya da yetkiliye dayandırılmamış ve ateş açmak ile kalabalığı kışkırtmak arasında nedensellik kurulmaya çalışılmıştır. Diğer eyaletlerde de gösterilerin yapılması, protestocuların şiddet eylemleriyle aktarılmıştır. Haberde kullanılan fotoğraflar haber metni ve başlığıyla uyumludur. Gösterileri yansıtan Fotoğraf 12 ve 13, haber metnini destekleyecek şekilde verilmiştir. Protestocuların polisle karşı karşıya olduğu Fotoğraf 14 kurulan karşıtlığı ve güç gösterisini yansıtmaktadir. 


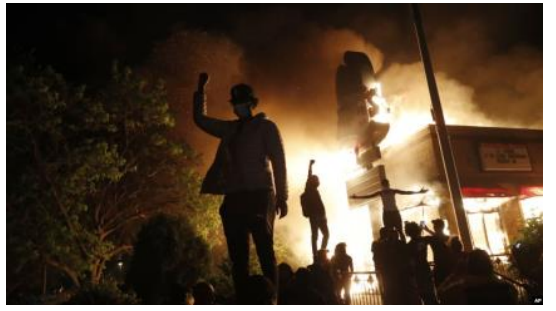

Fotoğraf 12. 30 Mayıs 2020 tarihli 2. haber

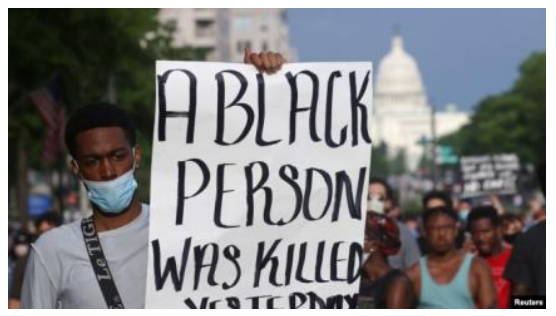

Fotoğraf 13. 30 Mayıs 2020 tarihli 2. haber

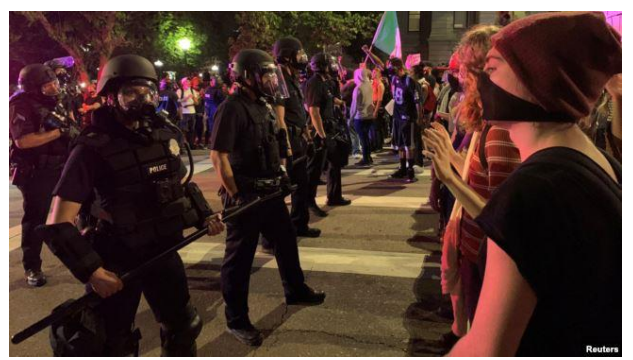

Fotoğraf 14. 30 Mayıs 2020 tarihli 2. haber

30 Mayıs tarihli üçüncü haberin başlığ “ "ABD'de Protestolar ve Polisle Çatışmalar Yayılıyor" olarak verilmiştir. Önceki günlerde gösteriler ve protestolar ifadesi kullanılırken, polisle çatışma ifadesi kullanılmaya başlanmıştır. Haberin girişinde olayın ortaya çıkışı bildirilerek art alan bilgisi verilmiştir. "19 yaşındaki protestocunun kalabalığın üzerine aracını süren ve ateş açan bir kişi tarafından vurulduğu öne sürüldü." cümlesinde protestocunun vurulması "öne sürüldü" edilgen fiili kullanılarak bir iddia olarak sunulmuştur. "Bazı göstericiler de Amerika bayrağı yaktı." cümlesi kullanılarak, gösterilerle vatandaşlık ve ülke aidiyeti arasında karşıtlık kurulmuştur. "Polis memuru Chauvin için 500 bin dolar kefalet bedeli belirlendi" ara başlı̆̆ı kullanılmış, haberin devamında soruşturmanın seyri ve yargılamanın nasıl yapılması gerektiği konusunda gerekli bilgiler sorgulayıı bir ifadeyle aktarılmamıştır. "Washington Post gazetesi Chauvin' in karısının da tutuklu polis memuru hakkında boşanma davası açtı̆̆ını yazdı." cümlesi kullanılarak öznelleştirme yapılmıştır. Boşanma davası açılması ve polis memurunun cinayetle suçlanması arasında bağlantı kurulmaya ve polis memuru hakkındaki olumsuz imaj pekiştirilmeye çalışılmıştır. Haberde ülkedeki sivil haklar gruplarından biri olan NAACP'in başkanı Derrick Johnson'ın Amerika'nın Sesi'ne verdiği demeçteki “Biz ırkçılık konusuyla değil, Minneapolis'teki Afrika kökenli Amerikalıların hayatlarının, değerleri 
konusuyla mücadele ediyoruz" söylemi aktarılmış, ancak haberde ırkçılık konusu üzerinde fazla durulmamıştır. Trump'ın Twitter hesabında göstericileri haydutlar olarak nitelemesi verilmiştir. Resmi yetkililerin söylemlerinin kitleler üzerindeki etkisi nedeniyle medyanın seçerek aktardığı sözcükler de önemli olmaktadır. Trump'ın yağma olursa polisin de silah kullanmaya başlayacağını belirtmesi üzerine Twitter Şirketi'nin Trump'ın paylaşımına "şiddet unsurlarını övdüğ̈̈" için uyarı mesajı koyduğu bilgisi verilirken, bu tweet için haberde "Trump'tan şiddet imalı tweet" ara başlı̆̆1 kullanılmıştı. Minneapolis Belediye Başkanı Frey ve Portland Belediye Başkanı Ted Wheeler'in barışçıl eylem çağrıları da kitleyi ikna amaçlı retorik olarak haberde verilmiştir. Minnesota Valisi Tim Walz'ın da Trump'ın açılamalarına tepki gösterdiği bildirilerek, Trump'ın tavrı ve diğer yetkililerin yaklaşımı arasında bir karşılaştırma da aktarılmıştır. ABD'nin ilk siyahi başkanı Obama'nın ırkçılık için “Bu 2020 yılının Amerika'sında normal olmamalı. Bu normal olamaz" söylemi aktarılarak haberde ırkçılık konusuna değinilmiştir. Haberin devamında polis memuru Chauvin'in görev süresince benzer suçlamaların olduğu bildirilmiş ve olumsuz olaylar bir araya getirilerek bir imaj çizilmeye çalışılırken öznelleştirme yapılmıştır. Bu öznelleştirme asıl konudan uzaklaşılmasına neden olmakta ve olay polisin siyahilere uyguladığı şiddet ve ırkçı bakış açısı olarak değil de, bir polisin mesleğe uymayan davranış biçimi olarak yansıtılmaktadır. "ünlü Louis Vuitton mağazasının yağmalandığı ve dükkandaki binlerce dolarlık çantaların çalındığı belirtildi" cümlesinde yine bir marka üzerinden haberi kurgulama ve göstericileri yoksullukla ilişkilendirerek markayı ön plana çıkarma söz konusudur. Önceki haberde 19 yaşındaki protestocunun ölümü için "öne sürüldü" fiili kullanılırken, mağaza için daha kesin bir ifade olan "belirtildi" fiili kullanılmıştır. "Polis müdahaleden önce Twitter hesabından bir uyarı mesajı da yayınladı" cümlesi polisin şiddet yanlısı olmadığı, göstericilerle çatışmadığı, ırkçı olmadığı algısını yaratmak amacıyla kullanılmıştır. Başlık ve haber metniyle uyumlu fotoğraflar yayınlanmıştır. Önceki tarihlerdeki haberlerde polis göstericilerle karşılıklı olarak gösterilirken, polisin protestoculara müdahale ettiği fotoğrafa yer verilmiştir. Fotoğraf $15^{\prime}$ te Trump'ın şiddet iması desteklenmiştir. Gösterilerde siyah ve beyaz elin havaya kaldırıldığı Fotoğraf $16^{\prime}$ da, siyah el daha net, beyaz el ise daha flu gösterilmiştir. Gösterilere sadece siyahiler katılmamasına rağmen, siyah el daha net verilerek vurgulanmıştır. Polis memurunun diziyle Floyd'un boğazına bastırdığı görüntü- 
yü andıran Fotoğraf 17 kullanılmıştır. Protestocuların arkaları dönük, ellerini kaldırarak diz çöktüğü, polisin ise karşılarında ayakta ve silahlı olduğu Fotoğraf 18, gücün önünde diz çökmeyi, geri çekilmeyi ve teslim olmay1 çağrıştırmaktadır.

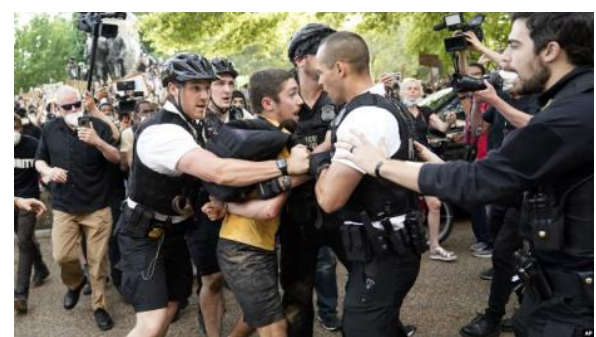

Fotoğraf 15. 30 Mayıs 2020 tarihli 3. haber

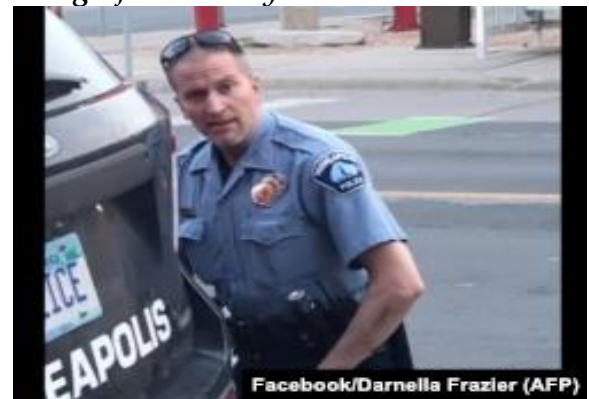

Fotoğraf 17. 30 Mayıs 2020 tarihli 3. haber

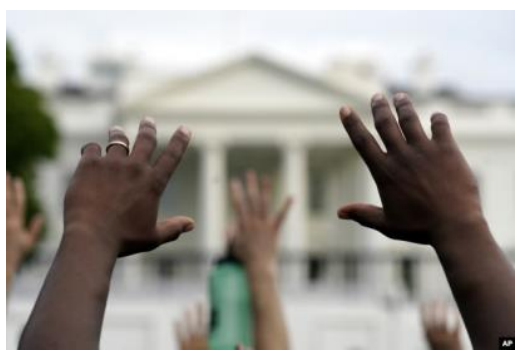

Fotoğraf 16. 30 Mayıs 2020 tarihli 3. haber

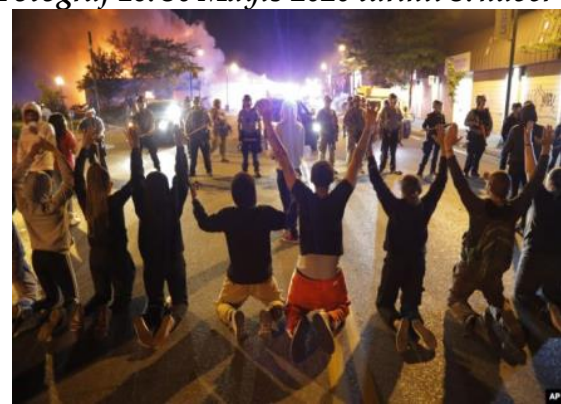

Fotoğraf 18. 30 Mayıs 2020 tarihli 3. haber

31 Mayıs tarihli haberde "Çetelerin Şiddet Saçmasına İzin Vermeyeceğiz" başlığı kullanılmıştır. Başlıkta Trump'ın söylemi doğrudan alıntı olarak tırnak içinde verilmiştir. Haberin devamında Trump'ın hukukun üstünlüğünü vurguladığı bildirilerek, "Görevimiz nefret değil iyileştirme, kaos değil adalet olmalı" söylemi aktarılmıştır. Trump, hukuk ve adalet yanlısı olarak yansıtılmıştır. Sonrasındaki cümlede ise Trump'ın güvenlik birimlerinin daha sert taktiklere başvurulmasını destekleyen mesajları Twitter üzerinden paylaştığı bildirilmiş ve gösterilerin önlenmesi konusunda yapılabileceklere dair bir uyarı olarak yansıtılmıştır. Haberin başlığı, haber metni ve fotoğraf uyumludur. Fotoğraf $19^{\prime}$ da Trump'ın konuşma yaptığı bir kare kullanılarak haber metni desteklenmiştir. 


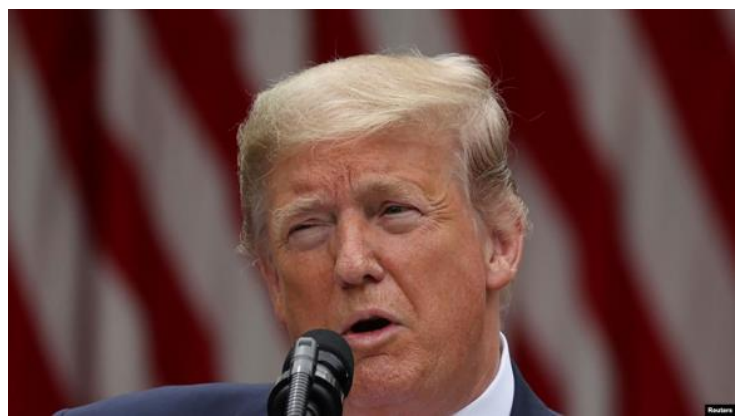

Fotoğraf 19. 31 Mayıs 2020 tarihli haber

1 Haziran tarihli birinci haberin başlığ 1 “ABD'deki Polis Karşıtı Gösteriler Brezilya'ya da Sıçradı" olarak verilmiştir. Fakat başlıkta eksik bilgi verilmiş ve Brezilya'da polis karşıtı eylemlerin nedeni hakkında bilgi aktarılmamıştır. Haberin girişinde art alan bilgisi verilerek, Floyd'un ölümü üzerine gösteriler düzenlendiği bildirilmiş ve başlıktaki ifade yinelenmiştir. Haberin devaminda Brezilya'daki gösterilerin polisin ülkede "favela" olarak bilinen yoksul mahallelerde yaşayan siyahilere yönelik tavrını protesto etmek için yapıldığı bilgisi aktarılmıştır. Polis ile yoksul mahallede yaşayan siyahiler karşıtllğ̆ üzerinden genelleştirme yapılarak, siyahi olmak ve yoksul olmak ilişkilendirilmiştir. Brezilya'da 14 yaşında bir çocuğun Favela'da düzenlenen operasyon sonucu öldürülmesine değinilerek art alan bilgisi verilmiştir. "Rio polisi geçen yıl 1546 sivili düzenlediği operasyonlar sırasında öldürdü." cümlesinde sayısal verilerle polis şiddetinin boyutu hakkında bilgi verilirken, "öldürdü" etken fiili kullanılmıştır. Floyd'un ölümü ile ilgili haberlerde ise ABD'de siyahilere yönelik olaylarda polis şiddetine maruz kalanlarla ilgili sayısal bir bilgiye yer verilmemiştir. Haberin genelinde siyahi, yoksul, şiddet yanlısı, suça eğilimli temaları bağlamında bir ilişkilendirme söz konusudur. Haberde kullanılan iki fotoğraftan Fotoğraf 20 gösterileri ve çatışmayı, Fotoğraf 21 ise yoksulluğu simgelemektedir. Fotoğraflar haber metnini desteklemektedir. Sadece Fotoğraf 20 başlığı yansitmaktadır. 

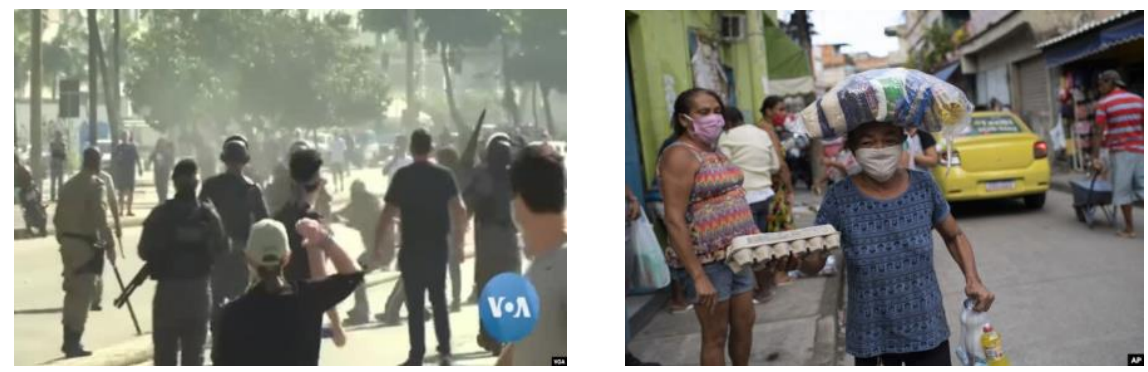

Fotoğraf 20. 1 Haziran 2020 tarihli 1. haber Fotoğraf 21. 1 Haziran 2020 tarihli 1. haber

1 Haziran tarihli ikinci haberde "Trump Adalet Bakanı'yla Protestoları Değerlendirecek" başlığı kullanılmıştır. Başlıktaki ifade Trump'ın tek karar verici olmadığına, yasalara göre hareket ettiğine, adaleti uygulamaya çalıştığına gönderme yapmaktadır. Haberin girişinde başlıktaki ifade yinelenmiştir. Haberde protestoların şiddetini anlatmak için "Martin Luther King suikastından bu yana en kapsamlı sokağa çıkma yasakları" ara başlığı kullanılmıştır. Araçların ateşe verildiği ve mağazaların yağmalandığı tekrar edilerek art alan bilgisi de verilmiştir. Haberde "George Floyd'un polis nezaretinde yaşamını yitirmesi, siyahların son yıllarda maruz kaldığı benzer olayların sonuncusu." cümlesi yorum içermektedir. Floyd'un ölümüne polislerin neden olması "nezaretinde" sözcüğü kullanılarak, polisin olaya dahil olmadığı algısı yaratılmaya çalışmıştır. "benzer olaylar" ifadesiyle genelleme yapılmış, "maruz kaldığı" söylemiyle de çaresizlik çağrışımı yapılmıştr. "Olaylar seçim öncesi kutuplaşma yaşayan ülkede öfkeyi körükledi" ara başlı̆̆ kullanılmış, öfkenin sebebi polis şiddeti ve ırkçlık olduğu halde, ırkçılık karşıtı protestolar sebep olarak gösterilmiştir. Polis şiddeti sonucu bir kişinin yaşamını yitirmesi ana olay iken, ara başlıkta seçim ön plana çıarılarak, gösterilerin seçim sonuçları üzerindeki etkisi tartışmaya açılmıştır. Sonrasındaki ara başlıkta ise "Muhalifleri Trump'ı rrksal gerginlikleri körüklemekle suçluyor" ifadesi kullanılmış ve gerginlikleri körükleyen kişinin Trump olduğu ifadesi muhaliflerin söylemine dayandırılarak aktarılmıştır. "Protestolar salgın sonrası normalleşme sürecinde kaygı yaratıyor" ara başlı̆̆ ile protestoların sonlandırılması için salgın gerekçe olarak sunulmuştur. Ara başlı̆̆ın devamında salgınla ilgili çok az bilgiye yer verilirken, bazı eyaletlerde barışçıl protestoların yapıldığı ve polisin üçüncü derece cinayet suçlamasıyla tutuklanmasının protestoları yatı̧stırmadığı bildirilmiştir. Haberin başlığı haber metninin tümünü yansıtmamaktadır. Haber 
metninde yaklaşan seçim, salgın, muhalifler konu edilerek bağlam dişına çıkılmıştır. Protestoyu yansıtan Fotoğraf 22 başlıkla uyumlu olmasına rağmen, haber metninin tümünü temsil etmemektedir.

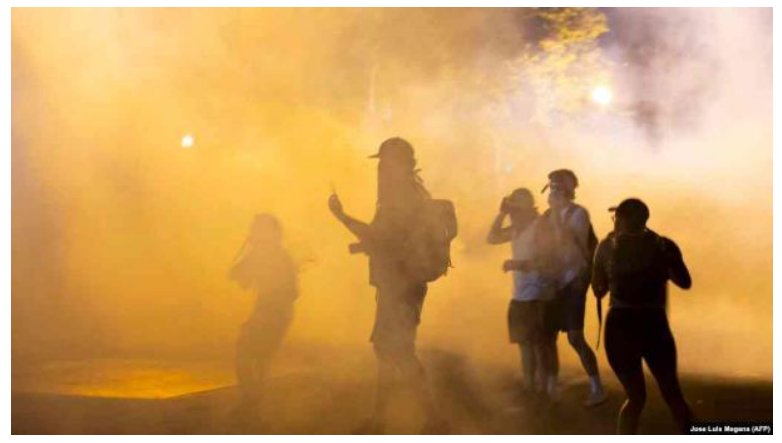

Fotoğraf 22. 1 Haziran 2020 tarihli 2. haber

2 Haziran tarihli ilk haberde "Trump Valilere "Zayıfsını" Dedi Daha Fazla Gözaltı Çağrısı Yaptı” başlığı kullanılmıştır. Önceki gün yayınlanan haberde kutuplaşmanın öfkeyi körüklediği aktarılırken, 2 Haziran'da Trump'ın daha fazla gözaltı çağrısı başlıkta bildirilmiştir. "Zayıf" sözcüğü başlığa çekilerek valilerin olaylara müdahale etmekte yetersiz ve çaresiz oldukları çağrışımı yapılmıştır. Haberin girişinde Trump'ın eylemcilere daha fazla baskı uygulanması isteği ve daha fazla kişinin gözaltına alınması çağrısı verilmiştir. Haberin devamında dükkanların yağmalanması, anıtlara zarar verilmesi, polis arabaları dahil bazı araçların yakılması ve eylemcilerin polisle çatışmaya girdiği bilgisi verilerek, Trump'ın çağrısı gerekçelendirilmiştir. "gösterilerden biri ABD Başkanı'nın konutu olan Beyaz Saray'ın tam karşısındaki caddede yapıldı." cümlesiyle de Trump'ın çağrısına gerekçe gösterilmiştir. Protestolar için Vietnam savaşı karşıtlarının ardından en geniş kapsamlı gösteriler yorumu aktarılarak benzetme kullanılmıştır. Haberde ilk defa polis memuru Chauvin'in kasıtsız adam öldürmeyle suçlandığ 1 bilgisi verilmiştir. "Polis barikatlar kurarak göstericileri uzaklaştırmaya çalıştı, göz yaşartıcı gaz kullandı." cümlesiyle polis saldırı değil, savunma konumunda gösterilmiş ve etken fiil kullanılmıştır. "Bazı kentlerden olayları görüntüleyen gazetecilerin polis tarafından yaralandığına dair haberler geldi." cümlesinde ise polisin saldırı konumunda olduğu edilgen fiille aktarılmıştır. Beyaz Saray'ın karşısındaki kalabalık için şok bombası kullanıldığı bilgisi de verilmiştir. Haberlerde genellikle resmi yetkililerin ya da makam- 
ların açıklamalarına yer verilmekte, göstericilerin görüşleri yansıtılmamaktadır. "Göstericiler polisin sert uygulamalarının özellikle siyah kadın ve erkekleri hedef aldığını ayrıca ABD'de sistematik şekilde ırkçılık yapıldığını savunuyor." cümlesiyle haberde göstericilerin görüşüne yer verilmiş ve ırkçlık göstericilerin iddiası olarak sunulmuştur. Başlıkta Trump'ın valilere eleştirisi aktarılırken, haber metninin bir kısmında başlık konusuna yer verilmiştir. Fotoğraf 23 başlığı tam olarak yansıtmamış, polislerin tetikte beklediği kare sunulmuştur.

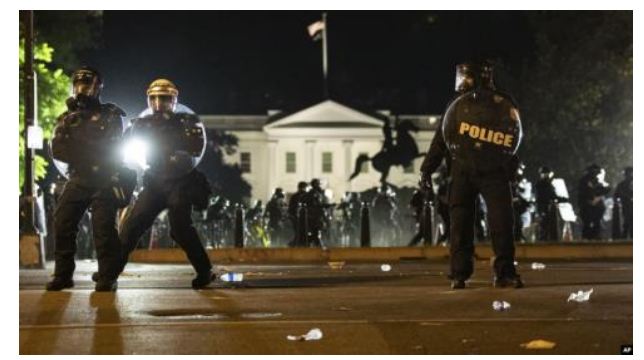

Fotoğraf 23. 2 Haziran 2020 tarihli 1. haber

2 Haziran tarihli ikinci haberin başlı̆g "Floyd'un Ölümünde İki Otopsi Farklı Bulgular" olarak kullanılmıştır. Haberin girişi "ABD genelinde şiddetli protestolara neden olan ölümle ilgili bağımsız otopsi tamamlandı." cümlesiyle başlamış, kişi ve ana olay yerine, protestolar ön plana çıkarılmıştır. Floyd için "siyah Amerikalı" nitelemesi kullanılarak, siyahi olması yine ön plana çıkarılmıştır. Bağımsız otopsi yapan doktorun, bulgularının solunum yolundaki engellerle uyumlu olduğunu söylediği açılama verilerek, uzman görüşü ile habere kesinlik kazandırılmıştır. Otopside Floyd'un ailesi adına bulunan diğer doktorun, diğer iki polisin Floyd'un sırtına baskı yapması nedeniyle oksijenin akciğerlerine gitmemesinin de ölümde etkili olduğunu belirtmesiyle haberde uzman görüşü verilmiştir. Bağımsız otopsinin sonuçlarının, Hennepin ilçesi Adli Tıp uzmanının bulgularıyla ters düşmesinin haberde belirtilmesiyle açılanan resmi raporun doğruluğu konusundaki şüpheye de göndermede bulunulmuştur. Floyd'un anıldığ1 fotoğraf kullanılmıştır. Fotoğraf 24 otopsi sonuçları arasındaki çelişkiye dair olmadığından haber metni ve başlikla uyumsuzdur. 


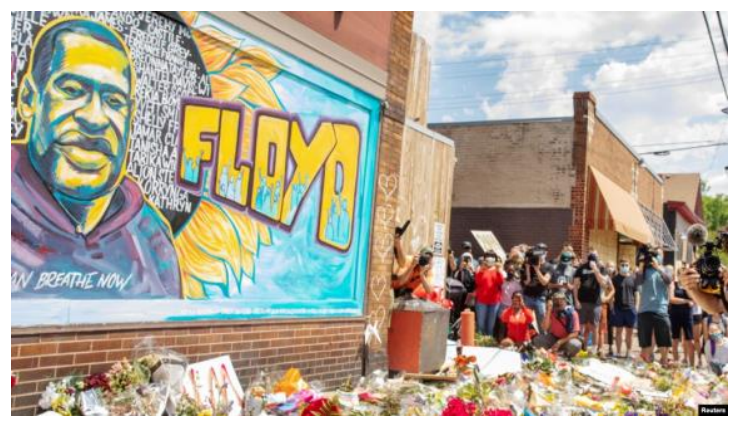

Fotoğraf 24. 2 Haziran 2020 tarihli 2. haber

2 Haziran tarihli üçüncü haber başlığı “Eyaletler Önlem Almazsa Ordu Devreye Girecek" olarak verilmiştir. Haber girişinde polisin harekete geçtiği bilgisi verilmiştir. Trump'ın gerektiği takdirde askeri müdahalede bulunulması yönünde talimat vereceği uyarısı bildirilerek başlıktaki bilgi yinelenmiştir. Trump'ın diğer eyaletlerin sokakları denetim altına alamaması durumunda orduyu göndereceği açıklaması verilerek, Trump'ın ve diğer eyaletlerin protestolara yaklaşımı konusundaki farklılık üzerinden karşıtlık kurulmuştur. Trump'ın “Eğer şehirler buna uymazsa ABD ordusunu göndererek onlar için sorunu hızla çözeceğim" açıklamasıyla eyalet valilerinin gerekli tedbirleri almadıkları algısı da yansıtılmıştır. Trump'ın protestocuların polise saldırısını iç terör eylemi olarak nitelemesine yer verilerek, protestocular bir tehdit olarak gösterilmiştir. Protestocuların eylem yaptığı Lafayette Parkı'nı polisin boşaltması sonrası Trump'ın parktan yürüyerek geçmesi haberde verilerek, egemen güç olduğu algısı yaratılmıştır. Protesto olayları sırasında bodrum katında yangın çıkan Saint John's Kilisesi önünde Trump'ın elinde İncil tutarak fotoğraf çektirdiği bilgisi verilerek, egemen güç olması Tanrı'ya olan inancı ile ilişkilendirilmiştir. Haber metnindeki açıklamaları destekleyen fotoğraflar kullanılmıştır. Fotoğraf 25 'te elinde İncil tutan devlet başkanının siyasal gücü tanrısal güçle ilişkilendirilerek, hem kitle üzerinde siyasal bir egemenliğinin olduğu hem de Tanrı'ya olan inancı ile adaleti korumak için harekete geçtiği yansıtılmaya çalışılmıştır. Fotoğraf 26'da, Trump'ın göstericilerin eylem yaptığı parkı yürüyerek geçmesi ve yanında askerlerin olması, protestoların bastırılmasında sahip olduğu güce ve son karar verici oluşuna vurgu yapmaktadır. 


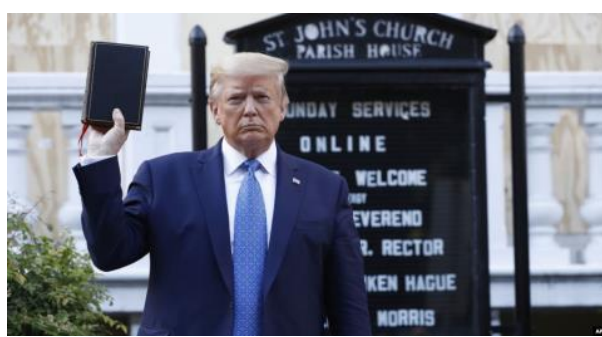

Fotoğraf 25. 2 Haziran 2020 tarihli 3. haber

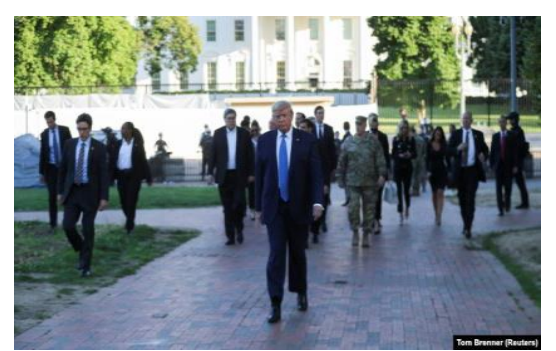

Fotoğraf 26. 2 Haziran 2020 tarihli 3. haber

2 Haziran tarihli dördüncü haberde “ABD'deki Gösterilerde 5 Polis Memuru Vurularak Yaralandı" başlığ 1 kullanılmıştır. Haberin girişinde "Amerika'da George Floyd adlı siyahın polis tarafından gözaltına alındığı sırada nefessiz kalarak ölmesi sonucu başlayan gösteriler ülke genelinde sürüyor." cümlesinde "George Floyd adlı siyahın" ifadesi haber öznesini önemsizleştirmiştir. Ülke geneline ve diğer ülkelere yayılan gösterilerin sebebi George Floyd'un ölümü olmasına rağmen, giriş cümlesinde ötekileştirme, ana olayı gösteriler olarak sunma söz konusudur. Gösterilerde vurulan ve yaralanan polislerin olduğu bilgisi verilirken, yaralanan göstericiler olup olmadığ konusunda bilgi verilmemiştir. St. Louis Polis Teşkilatı'nın Twitter hesabından polislere şehir merkezinde ateş edildiğini bildirdiği açıklamaya yer verilirken, polisin siyahilere ve eylemcilere müdahalesi hakkında bilgi aktarılmamıştır. Haber 23 eyalet ve başkentte Ulusal Muhafızlar'ın görevlendirildiği bilgisiyle sona erdirilerek, müdahalelerin devam edeceği algısı sürdürülmüştür. Haber başlığı haber metniyle uyumludur. Fotoğraf $27^{\prime}$ de ise polis müdahalesi yansitılarak, haber başlı̆̆1 ve metniyle uyumsuz fotoğraf kullanılmıştır.

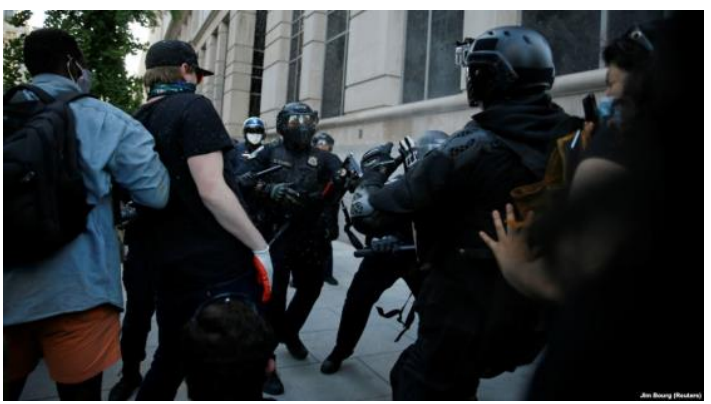

Fotoğraf 27. 2 Haziran 2020 tarihli 4. haber 
2 Haziran tarihli beşinci haberin başlı̆̆ “Floyd'un Ölümünün Dünyada Neden Olduğu Tepki Büyüyor" olarak verilmiştir. Başlık ana olay olan Floyd'un ölümünü ve sonrasında yaygınlaşan tepkileri bildirmiştir. Haber girişi "Siyah Amerikalı George Floyd'un gözaltına alınırken yaşamını yitirmesi Paris'ten Sydney'e dünyanın dört bir yanında protesto edildi." cümlesiyle verilmiştir. Giriş cümlesinde "gözaltına alınırken yaşamını yitirmesi" ifadesinde olay ön plana çıarılmış, polis memurlarının etkisi hakkında bilgi verilmemiştir. Avrupa Birliği üst düzey yetkililerinden Josep Borrell'in "Şok olduk ve dehşete düştük" ifadesi ile Floyd'un ölümünün kabul edilemez ve korkutucu olduğu yansıtılmıştır. Sydney'de göstericilerin polis eşliğinde iki saat süren barışç bir yürüyüş gerçekleştirdikleri bilgisi verilerek, barışçı yürüyüşlere polisin müdahale etmediği mesajı verilmiştir. Avustralya'daki gösterilerde protestocuların yerli nüfusun ayrımcllık ve polis şiddetine maruz kaldığına dikkat çekmesi aktarılmış ve Guardian gazetesi kaynak gösterilerek Avustralya'da 1991 yılından itibaren 432 Avustralya yerlisinin gözaltındayken hayatını kaybettiği bilgisi verilmiştir. Haberde ABD'de siyahilerle ilgili böyle bir sayısal bilgi aktarımı yapılmamıştır. Haberin devamında diğer ülkelerde yapılan gösteri çağrıları ve Floyd'un ölümüyle ilgili tepki mesajları olduğu belirtilerek bağlam bilgisi verilmiştir. Borrell'ın Floyd'un öldürülmesinin "gücün istismarı" olduğu açılaması verilerek polisin orantısız şiddetine dikkat çekilmiştir. Borrell'ın "gerginliklerin giderilmesi için çağrıda bulunuyoruz" söylemi kitleyi ikna edici bir retorik olarak haberde verilmiştir. Almanya Dışişleri Bakanı Heiko Mass'ın “Bu protestoların ABD'de bir etkisi olmasını umduğumuzu da üstüne basarak belirtmek isterim” söylemi, Gana lideri Nana Akufo-Addo'nun “21'inci yüzyılda, demokrasinin büyük kalesi ABD'nin hala sistematik ırkçllık sorunuyla boğuşmaya devam etmesi doğru olmaz" ifadesi ve Kenya'nın eski Başbakanı Raila Odinga'nın "Amerika'yı vatan olarak benimseyen tüm insanlar için adalet ve özgürlük diliyoruz" söylemi ile ABD'nin rrkçılıkla yeterince mücadele etmediği mesajı verilirken, ABD'yi eleştiren söylemlere yer verilmesiyle de taraf dengesi sağlanmıştır. Başlık haber metniyle ve fotoğrafla uyumludur. Fotoğraf $28^{\prime}$ de kalabalık ve şiddet içermeyen gösteriden bir kesit yansitılmiştır. 


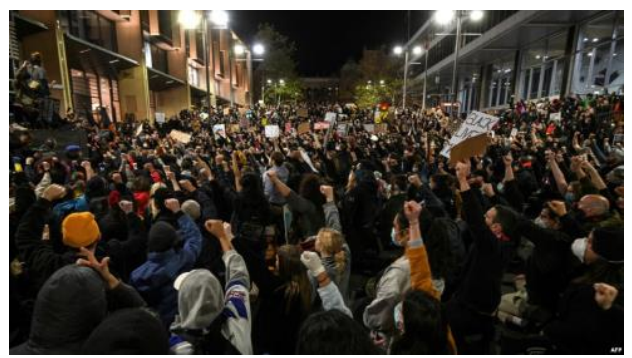

Fotoğraf 28. 2 Haziran 2020 tarihli 5. haber

2 Haziran tarihli altıncı haberde "Trump' 1 Kilise Ziyaretine Din Adamlarından Tepki" başlı̆̆ 1 kullanılmıştır. Giriş cümlesinde Trump'ın St. John's Kilisesi önünde İncil'le poz vermesine siyaset çevreleri ve din adamlarından gelen tepki bildirilmiştir. Washington Bölgesi Piskoposu Mariann Budde'nin Trump'ın kilisede sadece poz verip dua etmemesi eleştirisi haberde aktarılırken, Trump'ın davranışının göstermelik olduğuna göndermede bulunulmuştur. Haberde olaylar kronolojik olarak aktarılırken art alan bilgisi verilmiştir. Budde'nin ülkenin daha derin yaralarına odaklanılması çağrısı da kitleyi yönlendirmek için haberde verilmiştir. Budde'nin "Kiliseyi yeniden inşa ediliriz. Çocuk bakım evinin döşemesini değiştirebiliriz. Ama bir insan hayatını geri getiremeyiz" açılamasıyla ve piskoposluğun ilk siyahi başkanı Michael Curry'nin "Ülkemiz derin acı içindeyken böyle bir davranış sergilenmesi yaraların sarılmasına yardımcı olmuyor" söylemiyle kitleyi ikna edici retorik desteklenmiştir. "Başkan Trump'ın barışçı protestoculara müdahalenin ardından yaptığı kilise ziyaretine siyasi çevrelerden de tepki geldi." cümlesinde barışçı protestolara müdahale yapıldığı bilgisi verilirken, önceki haberlerde şiddet nedeniyle müdahalenin yapıldığı, barışçı protestolara müdahale edilmediği belirtilmiştir. Sonraki cümlede Trump'ın rakibi Joe Biden'ın barışçı protestocuların Beyaz Saray'ın önünde göz yaşartıcı gaz ve flaş bombası ile dağıtıldığını ifade ettiği açıklama ile de müdahalenin barış̧̧ı protestoculara yapıldığı yinelenmiştir. Haberde Trump-Biden karşıtllğı protestolara müdahale üzerinden kurulmuştur. Biden'ın polis reformu çağrısı ifade edilerek, Trump'la olan karşıtlığı da sürdürülmüştür. Trump müdahalenin şiddet içerikli protestolara yapıldığını, Biden ise barışçı protestolara yapıldığını savunmaktadır. Temsilciler Meclisi'nin Demokrat partili Başkanı Nancy Pelosi'nin “Başkan'ın görevlerinden biri ayrışmanın yaralarını sarmaktır" söylemi ile Senato'nun azınlıktaki Demokrat Parti 
lideri Chuck Schumer'ın “Başkan'ın zayıf bir adamı güçlü biri gibi gösterme ihtiyacı" ifadesi Trump'ın kendi iktidarını düşünen bir lider olduğu algısını yaratmaktadır. Fotoğraf 29, Trump’ın Beyaz Saray'dan çıkış anını gösterdiğinden haber metni ve başlıkla uyumlu değildir.

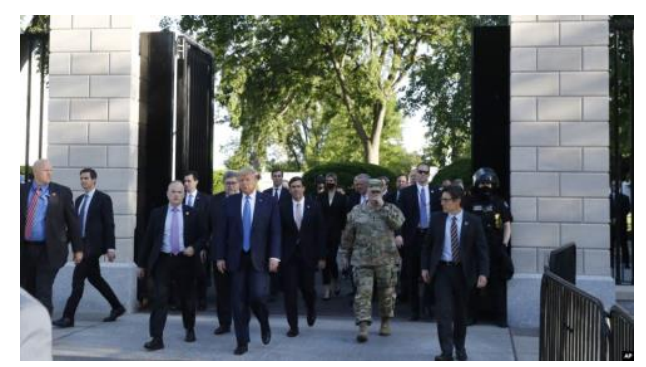

Fotoğraf 29. 2 Haziran 2020 tarihli 6. haber

\section{Bulgular}

Haber başlıklarında genel olarak Floyd'un ölümü sonrasındaki şiddet olaylarına dikkat çekilmiştir. Ana olay Floyd'un ölümü olmasına rağmen ana olayın sonrasındaki tepkiler ön plana çıarılarak, ana olay ve haber öznesi önemsizleştirilmiştir. Ana olay siyahilerin karşılaştıkları ırkçı yaklaşım ve şiddet olaylarından, siyahilerin gösterdikleri şiddete dönüşmüştür. Haber girişlerinde de başlıktaki temalar biraz daha ayrıntılı olarak aktarılmıştır. Başlıklar ve fotoğraflar çoğunlukla haber metniyle uyumlu olarak verilmiştir. Fotoğraflarda genellikle gösterilerden kesitler aktarılmıştır. İdeoloji ve anlam yüklü fotoğraflar kullanılmıştır. Haber metninde kurulan karşıtlıkları simgeleyen fotoğraflar haber metnini desteklemiştir.

Ana olay olan Floyd'un öldürülmesi, sonrasındaki tepkilerle, polislerin yargılanma süreciyle ve resmi yetkililerin açıklamalarıyla birlikte sunulmuştur. Art alan bilgisi olarak daha önce de yaşanan benzer olaylar aktarılmıştır. Siyahilerin karşılaştıkları ırkçı saldırılara haber metinlerinde birkaç örnek verilmiştir. Bağlam bilgisi açısından değerlendirildiğinde, siyahilerin suç, yoksulluk, şiddet, yağma ile ilişkilendirildiği görülmüştür. Haber metninde egemen söylem bağlam bilgisiyle yeniden üretilmiştir. Haber kaynakları olarak resmi yetkililer ve kurumlar gösterilmiş ve habere kesinlik katılmıştır. FBI, Minneapolis Belediye Başkanı Jacob Frey, Vali Tim Walz, ABD Başkanı Donald Trump, Polis sendikası, Adalet Bakanlığı, Savunma Bakanlığı, Beyaz Saray, Avrupa Birliği üst düzey yetkilileri haberde kaynak olarak 
gösterilmiştir. Olayın tarafları siyahiler, göstericiler, polis ve resmi kurumlar olarak aktarılmıştır. Protesto haberleri aktarılırken göstericiler ve polis karşıtlı̆̆ üzerinden olayın tarafları tanımlanmıştır.

Cümle yapılarına bakıldığında ise resmi kurum ve yetkililerin açıklamaları etken fiil yapısıyla aktarılırken, protestolarla ilgili cümlelerde "canlı yayın yapan televizyon kameralarına yansıdı", "görülüyor", "belirtiliyor" ifadeleriyle edilgen fiil yapıları kullanılmıştır. Cümleler arasında nedensonuç ilişkisi kurularak, gerekçeler hakkında bilgilendirme yapılmıştır. "Siyah" gibi ötekileştirici, "Floyd adlı siyahın" gibi özneyi önemsizleştirici sözcükler kullanılarak haber söylemi inşa edilmiştir. Haber retoriği açısından kullanılan fotoğrafların haber metnini tamamladığı, yetkililerin açıklamalarıyla habere kesinlik kazandırılarak hedef kitlenin ikna edilmeye çalışldı̆̆ı gözlemlenmiştir.

\section{Sonuç}

Bir grubun öteki üzerindeki egemenliğinin gerekçelerinden biri olarak sunulan rrkçllık, siyasi, ekonomik, toplumsal alanda kurulan eşitsiz iktidar biçimlerinin temellendirilmesinde kullanılmaktadır. 'Öteki'nin varlığına ihtiyaç duyan 'biz' tanımlaması, ırkçılık kavramına başvurmaktadır. Yasalardaki soyut eşitlik, toplumsal sistem içinde karşılık bulmadığından ötekileştirme pratikleri bir yaptırımla karşılaşmamaktadır. Kendini olumlu sunmak bile diğerini örtülü bir şekilde olumsuz sunmaya neden olmaktadır. Susturulan azınlık kamusal alanın dışında konumlandırılmaktadır. Eşitsiz yapı azınlıkları yok sayarak varlığını sürdürmektedir. Nefret söylemi, öteki olanı tanımlamak için olumsuz nitelikleri ön plana çıkarmakta ve ötekileştirilen kitleyi toplumdaki sorunların kaynağı olarak göstermektedir. Nefret söylemi çoğu zaman yan anlam düzeyinde belirsiz bir şekilde işlemekte ve ötekileştirme pratiği dil üzerinden sürdürülmektedir. Açık bir şekilde ifade edilmeyen nefret söylemi zihinleri yönlendirmekte ve dirençle karşılaşmamaktadır.

Medya egemen söylemi yeniden üretmekte ve kamuoyunun oluşmasına katkı sağlamaktadır. Medyanın gündem üzerindeki belirleyiciliği, karşı söylemlerin yok sayılmasına ya da manipüle edilmesine neden olmaktadır. Medya kamusal alanı şekillendirmekte, dikkatleri asıl konudan uzaklaştırarak zihinleri oyalamaktadır. Medya ırkçı olaylardaki şiddeti gösterirken, 
arka plandaki eşitsiz yapıyı görmezden gelmektedir. Azınlıklar haberde genellikle temsil olanağı bulmamakta, bulduklarında ise olumsuz sıfatlar ve adlandırmalarla yansıtılmaktadır. Azınlıkların haberde ön plana çıkarılması eşitsiz yapının ortaya çıkmasına neden olmakta, adalet, hukuk, demokrasi kavramlarının içini boşaltmakta ve egemenlerin iktidarını sarsmaktadır. Bu olumsuzlukları ortadan kaldırmak için medyada barış yanlısı gazetecilik ve hak odaklı habercilik esas alınmalıdır.

Bu çalışmada incelen haberlerde de Floyd'un ölümü sonrasındaki şiddet olaylarına dikkat çekilmiştir. Ana olay ve haber öznesi önemsizleştirilmiştir. Ana olay protestolar olarak sunulmuştur. İdeoloji ve anlam yüklü fotoğraflar kullanılmıştır. Haberde siyahiler suç, yoksulluk, şiddet ve yağma ile ilişkilendirilmiştir. Göstericiler ve polis karşıtlı̆̆ üzerinden öteki tanımlanmıştır. Resmi kurum ve yetkililerin açıklamaları aktif cümlelerle, protestolar pasif cümle yapılarıyla aktarılmıştır. Haberde ötekileştirici, özneyi önemsizleştirici sözcüklere yer verilmiştir. Hedef kitleyi ikna edici bir retorik kullanilmıştır.

Haberlerde göstericilerin söylem ve açıklamalarına yer verilmemiştir. Floyd'un ölümü sonrası yargılama sürecinin işleyişine dair bir sorgulama yapılmamıştır. Olayların şiddet boyutu ön plana çıkarılmış, konuyla ilgili polis şiddeti, yargılamanın adil olup olmadığı, toplumda siyahilerin karşılaştıkları ırkçı yaklaşım üzerinde çok fazla durulmamıştır. Polisin müdahale etmediği söylemi bile göstericilerin olumsuz olarak sunulmasına neden olmuştur. Olayın tarafı olarak resmi yetkili ve kurumların açıklamaları aktarllırken söylemleri yeniden üretilmiştir. 


\title{
EXTENDED ABSTRACT
}

\section{Analysis of George Floyd's Death News in the Context of Racism and Hate Discourse}

\author{
Çiğdem Tosun
}

Racism, presented as one of the reasons for the domination of one group over the other, is used to justify the unequal forms of power established in the political, economic and social spheres. The definition of 'we', which needs the presence of the 'other', refers to the concept of race. No sanction is imposed on practices of marginalization in the social system. Even presenting oneself positively causes the other to be presented negatively in disguise. The silenced minority is positioned outside the public sphere. Hate speech highlights the negative qualities used to define the other, and shows the marginalized mass as the cause of the problems in society. Hate speech often operates ambiguously at the connotative level. Practices of marginalization are maintained through discourse. Hate speech that is not clearly expressed directs the minds and does not encounter resistance.

Media reproduce the dominant discourse and contribute to the formation of public opinion. Since the media determines the agenda, it causes counter-discourses to be ignored or manipulated. The media shapes public opinion and distracts the minds by steering attention from the main topic to other topics. While the media shows the violence in the racist acts of violence, it ignores the unequal social structure behind it. Minorities generally do not have the opportunity to be represented in the news, and when they find the opportunity to be represented, they are reflected in negative words and are associated with negative events. The prominence of minorities in the news causes the emergence of an unequal structure, making the concepts of justice, law and democracy meaningless while undermining the power of the rulers. In order to eliminate these negativities, human rights oriented journalism should be taken as a basis.

In the United States, the events that followed the murder of George Floyd on May 25, 2020 turned into a mass reaction and spread to other countries. In this study, the news of George Floyd's death on 
www.amerikaninsesi.com was analyzed in the context of racism and hate speech. The aim of the study is to determine how the news of the death of George Floyd, who died as a result of police violence, was reflected on www.amerikaninsesi.com and how black people were viewed in the context of racism and hate speech. As the first news was published on 27 May, in line with the framework of the purposeful sampling method, the one week period between 27 May and 2 June was included in the analysis in this study. The seventeen pieces of news published in this one-week period were analyzed for the purposes of this study. Remarkable and meaningful photographs used in the news were also included in the analysis. Critical discourse analysis of Teun A. van Dijk was used as the research method.

In this study, the pieces of news were analyzed according to the thematic and schematic structure that van Dijk uses in discourse analysis. The headlines, news text and photographs were examined in detail to see whether they were compatible and how the main event was presented with background and context information, who the news sources were, which news sources were included more frequently, how the balance of sides and the opposition between the parties of the event was established. Finally, there was the analysis of the news pieces to track the use of active and passive verbs in the sentences, the meaningful words and photos selected, and news rhetoric.

Careful analysis of the news indicated that the incidents of violence that occured after Floyd's death were overemphasized. The main event and news subject were trivialized in that the former was presented as mere protests. Ideological and meaningful photos were used in the news. In the report, blacks were associated with crime, poverty, violence and looting. The marginalized were defined through the opposition between demonstrators and police. While official statements were conveyed by means active sentences, for the presentation of the protests, passive sentences were used. The words used were generally those that marginalize and trivialize the subject. A special form of rhetoric was used to convince the target audience.

Analysis of the news further indicated that the discourses and statements of the demonstrators were not included. After Floyd's death, there was no questioning of the functioning of the effectiveness of the trialing process. The aspect of violence was overemphasized. There was not much emphasis on police violence, the fairness of the trial or the racist approach 
faced by the blacks in society. Even the claim that the police did not intervene caused the negative presentation of the demonstrators. In the presentaiton of the statements by official institutions, the discourses were mostly reproduced.

\section{Kaynakça / References}

ABD Adalet Bakanlı̆̆: "Floyd Soruşturması Öncelikli". (2020, Mayıs 28) Amerika'nnn Sesi. 12 Temmuz 2020 tarihinde https://www.amerikaninsesi.com/a/adaletbakanligi-floyd-sorusturmasi-yuksek-oncelikli-/5439687.html adresinden erişilmiştir.

ABD'de Polis Karşıtı Gösteriler İkinci Gün de Devam Etti. (2020, Mayıs 28) Amerika'nnn Sesi. 12 Temmuz 2020 tarihinde https://www.amerikaninsesi.com/a/abd-depolis-karsiti-gosteriler-ikinci-gunde-de-devam-etti/5439022.html adresinden erişilmiştir.

ABD'de Protestolar ve Polisle Çatışmalar Yaylliyor. (2020, Mayıs 30) Amerika'nın Sesi. 12 Temmuz 2020 tarihinde https://www.amerikaninsesi.com/a/protestolarve-polisle-catismalar-abd-nin-dort-bir-yan\%C4\%B1na-yayildi/5442064.html adresinden erişilmiştir.

ABD'de Siyah Floyd'un Ölümü Tepkiyle Karşlandı. (2020, Mayıs 27) Amerika'nın Sesi. 12 Temmuz 2020 tarihinde https://www.amerikaninsesi.com/a/abdde-siyahbir-supheli-polis-siddetine-kurban-gitti/5437357.html adresinden erişilmiştir.

ABD'deki Gösterilerde 5 Polis Memuru Vurularak Yaralandı. (2020, Haziran 2) Ameri-

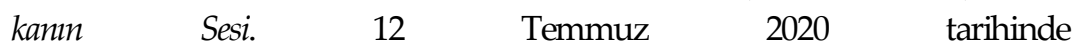
https://www.amerikaninsesi.com/a/abd-deki-gosterilerde-4-polis-memurusilahla-vurularak-yaralandi/5445609.html adresinden erişilmiştir.

ABD'deki Polis Karşıı Gösteriler Brezilya'ya da Sıçradı. (2020, Haziran 1) Amerika'nın Sesi. 12 Temmuz 2020 tarihinde https:/www.amerikaninsesi.com/a/abddeki-polis-karsiti-gosteriler-brezilya-ya-da-sicradi/5443924.html adresinden erişilmiştir.

ABD’nin Dört Bir Yanında Protestolara Şiddet Karıştı. (2020, Mayıs 30) Amerika'nnn Sesi. 12 Temmuz 2020 tarihinde https://www.amerikaninsesi.com/a/abd-nindort-bir-yaninda-floyd-icin-protestolara-siddet-karisti/5441946.html adresinden erişilmiştir.

Alankuş, S. (2013). 'Başka' bir habercilik ihtiyacı ve hak odaklı habercilik. M. Çınar (Ed.) Medya ve nefret söylemi. İçinde (s. 219-250). İstanbul: Hrant Dink Vakfı Yayınları. 
Arsan, E. (2005). Çatışma ve savaş dönemlerinde gazetecilik. S. Alankuş (Der.) Gazetecilik ve habercilik. İçinde (s. 125-136). (2.Basım). İstanbul: IPS İletişim Vakfı Yayinları.

Aydoğan, A. ve Başaran, F. (2012). Yeni medyayı alternatif medya bağlamında anlamak. Ö. Özer (Ed.) Alternatif medya alternatif gazetecilik. İçinde (s. 213-246). Konya: Literatürk Yayınları.

Binark, M. (2010). Nefret söyleminin yeni medya ortamında dolaşıma girmesi ve türetilmesi. T. Çomu (Haz.) Yeni medyada nefret söylemi. İçinde (s. 11-53). İstanbul: Kalkedon Yayınları.

Bourse, M. ve Yücel, H. (2017). Kültürel çalışmalarn anlamak. (Çev.: H. Yücel). İstanbul: İletişim Yayınları.

Chomsky, N. (2012). Medya gerçeği. (4. Basım). (Çev.: A. Yılmaz ve O. Akınhay). İstanbul: Everest Yayınları.

“Çetelerin Şiddet Saçmasına İzin Vermeyeceğiz". (2020, Mayıs 31) Amerika'nın Sesi. 12 Temmuz 2020 tarihinde https://www.amerikaninsesi.com/a/cetelerinsiddetine-izin-vermeyecegiz/5442812.html adresinden erişilmiştir.

Çınar, M. (2013). Habercilik ve nefret söylemi. M. Çınar (Ed.) Medya ve nefret söylemi. İçinde (s. 137-152). İstanbul: Hrant Dink Vakfi Yayınları.

Çomu, T. ve Binark, M. (2013). Yeni medya ortamlarında nefret söylemi. M. Çınar (Ed.) Medya ve nefret söylemi. İçinde (s. 199-216). İstanbul: Hrant Dink Vakfı Yayınları.

Debord, G. (2017). Gösteri toplumu. (7. Basım). (Çev.: A. Ekmekçi ve O. Taşkent). İstanbul: Ayrıntı Yayınları.

“Eyaletler Önlem Almazsa Ordu Devreye Girecek". (2020, Haziran 2) Amerika'nın Sesi. 12 Temmuz 2020 tarihinde https://www.amerikaninsesi.com/a/trumpeyaletler-onlem-almazsa-orduyu-devre-sokacagim-/5445462.html adresinden erişilmiştir.

Floyd'un Ölümünde İki Otopsi Farklı Bulgular. (2020, Haziran 2) Amerika'nın Sesi. 12 Temmuz 2020 tarihinde https://www.amerikaninsesi.com/a/floyd-unolumunde-iki-otopsi-farkli-bulgular/5445034.html adresinden erişilmiştir.

Floyd'un Ölümünde Polis Memuru Üçüncü Derece Cinayetle Suçlanıyor. (2020, Mayis 29) Amerika'nm Sesi. 12 Temmuz 2020 tarihinde https://www.amerikaninsesi.com/a/minneapolis-te-irksal-gerginlik-ve$\%$ C5\%9Fiddet- $\%$ C3\%BC $\%$ C3\%A7\%C3\%BCnc\%C3\%BC-gece-des\%C3\%BCrd\%C3\%BC-/5440905.html adresinden erişilmiştir. 
Floyd'un Ölümünün Dünyada Neden Olduğu Tepki Büyüyor. (2020, Haziran 2) Amerika'nnn Sesi. 12 Temmuz 2020 tarihinde https://www.amerikaninsesi.com/a/floydun-olumunun-dunya-capindayarattigi-infial-buyuyor-george-amerika/5446368.html adresinden erişilmiştir.

Gantt Shafer, J. (2017). Donald Trump's "Political incorrectness: Neoliberalism as frontstage racism on social media". 12 Temmuz 2020 tarihinde https:/journals.sagepub.com/doi/pdf/10.1177/2056305117733226 adresinden erişilmiştir. 1-10.

George Floyd'un Ölümüne Tepkiler Büyüyor Protestolar Yayllyor. (2020, Mayıs 28) Amerika'nm Sesi. $12 \quad$ Temmuz 2020 tarihinde https://www.amerikaninsesi.com/a/siyah-amerikalinin-olumune-tepkilerbuyuyor-protestolar-yayiliyor/5439352.html adresinden erişilmiştir.

Göka, Ş. (2011). Siyaset, medya ve zihnime yansimalar. Ankara: Birleşik Yayınevi.

Göregenli, M. (2013a). Ayrımcllğın meşrulaştırılması. M. Çınar (Ed.) Medya ve nefret söylemi. İçinde (s. 39-54). İstanbul: Hrant Dink Vakfı Yayınları.

Göregenli, M. (2013b). Nefret söylemi ve nefret suçları. M. Çınar (Ed.) Medya ve nefret söylemi. İçinde (s. 57-73). İstanbul: Hrant Dink Vakfı Yayınları.

Göregenli, M. (2013c). Temel kavramlar: Önyargilar, özcü inançlar ve ayrımcllk". M. Çnar (Ed.) Medya ve nefret söylemi. İçinde (s. 23-37). İstanbul: Hrant Dink Vakfi Yayınları.

Grosfoguel, R. (2016). What is racism?. 9 Eylül 2020 tarihinde http:/jwsr.pitt.edu/ojs/jwsr/article/view/609/743 adresinden erişilmiştir. 9-15.

İnal, A. (1995). Yazılı basin haberlerinde "yapısal" yanlllk sorunu. Toplum ve Bilim. Sayl: 67. İçinde (s. 111-134). İstanbul: Birikim Yayınları.

İnal, A. (1997). Haber metinlerine eleştirel bir bakış: Temel sorunlar ve örnek çalışmalar. Ankara Üniversitesi Iletetşim Fakültesi Yılllk. İçinde (s. 135-163). Ankara: Ankara Üniversitesi Basımevi.

Morley, D. ve Robins, K. (2011). Kimlik mekanları. (2. Basım). (Çev.: Emrehan Zeybekoğlu). İstanbul: Ayrınt Yayınları.

Özer, Ö. (2015). Teun Adrian van Dijk örneğinde eleştirel söylem çözümlemesi. B. Yıldırım (Ed.) Iletişim araştırmalarnnda yöntemler. İ̧inde (s. 197-286). Konya: Literatürk Yayınları.

Rosenfeld, M. (2001). Hate speech in constitutional jurisprudence: A comparative analysis. 12 Temmuz 2020 tarihinde https://papers.ssm.com/sol3/papers.cfm?abstract_id=265939 adresinden erişilmiştrir. 1-63. 
Schiller, H. (2005). Zihin yönlendirenler. (2. Basım). (Çev.: C. Cerit). İstanbul: Pınar Yayınları.

Trump Adalet Bakanı'yla Protestolanı Değerlendirecek. (2020, Haziran 1) Amerika'nın Sesi. 12 Temmuz 2020 tarihinde https://www.amerikaninsesi.com/a/trumpve-adalet-bakani-barr-protestolaridegerlendirecek\%CC\%87\%CC\%87/5444317. html adresinden erişilmiştir.

Trump Valilere “Zayıfsınız” Dedi Daha Fazla Gözaltı Çağıısı Yaptı. (2020, Haziran 2) Amerika'nın Sesi. $12 \quad$ Temmuz $2020 \quad$ tarihinde https://www.amerikaninsesi.com/a/trump-valilere-zayifsiniz-dedi-dahafazla-gozalt\%C4\%B1-cagrisi-yapti/5444934.html adresinden erişilmiştir.

Trump: "Görüntüler Polis Teşkilatı İçin Hakaret”. (2020, Mayıs 30) Amerika'nın Sesi. 12 Temmuz 2020 tarihinde https:/www.amerikaninsesi.com/a/trumpgoruntuler-polis-teskilati-icin-hakaret/5441603.html adresinden erişilmiştir.

Trump'ın Kilise Ziyaretine Din Adamlarından Tepki. (2020, Haziran 2) Amerika'nmn Sesi. 12 Temmuz 2020 tarihinde https:/www.amerikaninsesi.com/a/trumpinkilise-ziyaretine-din-adamlarindan-tepki/5446396.html adresinden erişilmiştir.

van Dijk, T. A. (1988a). News as discourse. Hillsdale, NJ: Erlbaum.

van Dijk, T. A. (1988b). News analysis. Hillsdale, NJ: Erlbaum.

van Dijk, T. A. (1991). Racism and the press. London and New York: Routledge.

van Dijk, T. A. (1993). Elite discourse and racism. Newbury Park, CA: Sage.

VOA. (t.y.). Biz Kimiz? 8 Eylül 2020 tarihinde https://www.amerikaninsesi.com/p/3781.html adresinden erişilmiştir.

Wolf, R. ve Le Guin C. (2004). Race and racism illumination project curriculum materials. 9 Eylül $2020 \quad$ tarihinde https://www.pcc.edu/illumination/wpcontent/uploads/sites/54/2018/05/race-and-racism-curriculum.pdf adresinden erişilmiştir. 1-9.

\section{Kaynakça Bilgisi / Citation Information}

Tosun, Ç. (2020). Irkçılık ve nefret söylemi bağlamında George Floyd'un ölümü haberlerinin analizi. OPUS-Uluslararası Toplum Araştırmalarn Dergisi, 16(32), 5111-5152. DOI: 10.26466/opus.774524 